\title{
Paleoecological Successions from Shallow-marine Depositional Environments in Upper Silurian Carbonate Rocks of Blair County, Pennsylvania
}

\author{
Shadya El-Ashkar \\ West Virginia University, shadyaelashkar@gmail.com
}

Follow this and additional works at: https://researchrepository.wvu.edu/etd

Part of the Geology Commons, Paleontology Commons, Sedimentology Commons, and the Stratigraphy Commons

\section{Recommended Citation}

El-Ashkar, Shadya, "Paleoecological Successions from Shallow-marine Depositional Environments in Upper Silurian Carbonate Rocks of Blair County, Pennsylvania" (2020). Graduate Theses, Dissertations, and Problem Reports. 7902.

https://researchrepository.wvu.edu/etd/7902

This Thesis is protected by copyright and/or related rights. It has been brought to you by the The Research Repository @ WVU with permission from the rights-holder(s). You are free to use this Thesis in any way that is permitted by the copyright and related rights legislation that applies to your use. For other uses you must obtain permission from the rights-holder(s) directly, unless additional rights are indicated by a Creative Commons license in the record and/ or on the work itself. This Thesis has been accepted for inclusion in WVU Graduate Theses, Dissertations, and Problem Reports collection by an authorized administrator of The Research Repository @ WVU. For more information, please contact researchrepository@mail.wvu.edu. 


\title{
Paleoecological Successions from Shallow-marine Depositional Environments in Upper Silurian Carbonate Rocks of Blair County, Pennsylvania
}

\author{
Shadya El-Ashkar \\ Thesis submitted \\ to the Eberly College of Arts and Sciences \\ at West Virginia University \\ In partial fulfillment of the requirements for the degree of \\ Master of Science in \\ Geology \\ with concentration in \\ Paleontology
}

James C. Lamsdell, PhD., Committee Chair

Kathleen Benison, PhD.

Shikha Sharma, PhD.

Department of Geology and Geography

Morgantown, West Virginia

2020

Keywords: Silurian paleoecology, depositional environments, carbonate depositional systems, shallow marine invertebrates, transitional siliciclastic-carbonate environments, stratigraphy, paleontology, Appalachian Basin

Copyright 2020 Shadya El-Ashkar 


\section{ABSTRACT \\ Paleoecological Successions from Shallow-marine Depositional Environments in Upper Silurian Carbonates of Blair County, Pennsylvania}

\section{Shadya El-Ashkar}

Studies of paleoenvironment and paleoecology are important for investigating relationships between the different environmental and biological variables that influenced biodiversification patterns during the Silurian Period. The mixed carbonate and siliciclastic rocks of the Bloomsburg and Mifflintown Formations in central Pennsylvania represent transitions between carbonate ramp and deltaic settings. The goal of this study was to assess changes in depositional environment and paleoecology of an undescribed Bloomsburg/Mifflintown locality in Bellwood, Pennsylvania. In central Pennsylvania, the interfingered relationship of mixed carbonate and siliciclastic mudstones of the Mifflintown Formation with red fine-grained sandstones and shales of the Bloomsburg Formation presented challenges for deciphering the formations. Five stratigraphic sections were measured and described, in addition to identification of fossils and petrographic analysis of rock samples. A relatively diverse range of marine invertebrate fossils was observed, including ostracods, brachiopods, mollusks, crinoids, tentaculitids, bryozoa. orthocerid nautiloids, sponges, tabulate corals, and a rare eurypterid tergite. Nine lithologies were identified, including: (1) bioclastic wackestone-packstone, (2) siliciclastic mudstone, (3) mottled nodular-bedded packstone (4) fossiliferous mudstone-wackestone, (5) laminated peloidal grainstone, (6) recrystallized skeletal packstone, (7) intraclastic conglomerate and detrital carbonates, (8) massive microcrystalline carbonate, and (9) laminated brown calcareous mudstone. The observed fossil taxa were identified to study patterns in paleoecological and faunal community composition across different depositional environments. Based on lithological associations, four lithofacies were identified: (1) distal slope, (2) open lagoon and subtidal channels, (3) intertidal channels, and (4) tidal flat and channels. Most paleoenvironmental shifts were gradual. Paleoecology patterns assessed at the community-level illustrated variation in fauna based on substrate consistency and energy levels. The majority of paleoecommunities consisted of open marine fauna, with one community dominated by semi-restricted, brackish fauna. Faunal communities showed more variation in open marine environments such as ramp, open lagoon, and reef shoals. The undifferentiated Bloomsburg and Mifflintown Formations at Bellwood, Pennsylvania illustrate a general coarsening-upward sequence that reflects a shallowing of depositional environments likely relating to fluxes in siliciclastic sediment input, relating to lateral migration of a coastal delta, relative sea level change, or potentially both. Deposition was dominated by storm-driven processes, with lesser influence of tidal energy during periods of fair weather. The stratigraphy exposed at the Bellwood outcrop represents the evolution of a semi-protected, muddy, low-gradient carbonate ramp system, as it became influenced by siliciclastic influx associated with coastal delta progradation. 
Table of Contents

Title Page ... i

Abstract ... ii

Table of Contents ... iii

Acknowledgments ... iv

Introduction... 1

Study Background ... 2

Study objectives ... 4

Methods ... 5

Field work ... 5

Lab work ... 6

Results ... 7

Lithologies... 8

Discussion ... 17

Facies ... 17

Depositional system ... 21

Paleoecology ... 23

Conclusions ... 26

Depositional history ... 26

Paleoecological summary ... 27

Spatial Trends in Mifflintown/Bloomsburg Paleoecology ... 28

Future work ... 29

References ... 30

Figures ... 33 


\section{ACKNOWLEDGMENTS}

First, I would like to thank the Department of Geology and Geography at West Virginia University for making this project possible and for their great support throughout the entire process. I am very grateful to have become a part of the mountaineer geology family and the experience I have gotten through conducting this research project. A huge thanks to my thesis advisor, Dr. James Lamsdell, for giving me the rough idea for this project, roping the paleontology lab group into doing field work with me, and his general support throughout this project. I would like to thank my research committee members, Dr. Kathleen Benison and Dr. Shikha Sharma, for their feedback and very useful ideas. A special thanks to Dr. Benison for having discussions about my depositional environment interpretations. I would like to thank the WVU graduate department for awarding me a \$2000 research grant in spring 2019, which funded travel and lodging expenses for field work, as well as getting thin sections made from collected samples. I extend my gratitude to my fellow paleontology lab members (James Beech, Emily Hughes, Namiko Machida, Jessica Shulman, and Samuel Tybout), who have accompanied me in the field collecting rock and fossil samples and for their feedback on my research topics during lab meetings. A special thank you to Namiko Machida, who was my field assistant during a weekend trip to my study site, where she took photos (many of which I have used in my final thesis and defense), gave me useful field advice, and manually dug out trenches so I could actually see the limestone beds underneath all the shaly debris. Last but not least, I would like to thank my friends and family for their undying support, in no matter what I do or where I go, they are always cheering me on. 


\section{INTRODUCTION}

Throughout the history of life, paleoenvironmental change at various temporal and spatial scales has significantly influenced the ecological infrastructure of faunal communities, ultimately driving global biodiversification trends (Tackett and Bottjer, 2016; Holland and Patzkowsky, 2007). A fundamental phase for the evolutionary course of life, the early Paleozoic Era is characterized by major evolutionary events, including the Cambrian Explosion, Global Ordovician Biodiversification Event (GOBE), the late Ordovician-early Silurian mass extinction (Rasmussen et al, 2019; Lam et al, 2008), and the late-Devonian mass extinction. Such events have played significant roles in shaping the evolutionary and ecological mechanisms of early life (Jablonski, 2001). Collectively, biodiversity studies at various temporal scales contribute to the greater understanding of how global biodiversity operates in relation to abiotic and biotic changes (Rasmussen, 2019). Ecological change often corresponds to major changes in depositional conditions, reflected by sequence boundaries (Holland and Patzkowsky, 2007). The sequence stratigraphy of environmentally volatile periods provides a suitable archive to assess how physical environmental thresholds may influence paleoecological and paleocommunity turnover. Evaluating drivers of taxonomic change in habitats through time accentuates the abiotic and biotic variables that have influenced large-scale biodiversification patterns (Rasmussen, 2019).

A brief period often overshadowed by the plethora of studies on mass extinction events, the Silurian Period represents an intervening period of marine faunal recovery and turnover, afflicted by volatile shifts in sea level and bouts of ocean anoxia (Rasmussen, 2019; Cotter, 1990). The early Silurian is characterized by major evolutionary and ecological changes associated with the Late Ordovician mass extinction. However, studies of Upper Silurian marine biodiversity are relatively lacking (Rasmussen et al, 2019). Assessment of late Silurian paleoecological successions provides a comparative basis for evaluating the long-term impact of the end-Ordovician mass extinction on taxonomic turnover and faunal community compositions. Late Silurian paleoecological reconstructions serve as a precursor for the biodiversity trends into the Devonian period, yielding important implications regarding paleoecological and paleoecommunity stability prior to the end-Devonian mass extinction event. Evaluating paleoecological shifts in Silurian shallow marine invertebrate communities' aids in reconstruction of the large-scale environmental and biological events that impacted global 
biodiversity. By studying Silurian-aged sedimentary deposits, the role of Silurian abiotic and biotic events in shaping biodiversity patterns of Paleozoic life can be better understood. Studies of biodiversity recovery in the Silurian offer several major implications. Specifically, the second pulse of the Late Ordovician-Early Silurian mass extinction corresponds to global warming and can be treated as an analog for modern-day global change (Darroch and Wagner, 2015). Thus, assessing the biological aftermath of such a comparable event provides a basis for predicting future projections of the current biodiversity crisis. In broader context, recovery studies provide insight into the post-extinction evolutionary and ecological mechanisms that control trends in faunal community compositions, ultimately highlighting the essence of biodiversification recovery dynamics in shaping global biodiversity.

Understanding early Paleozoic biodiversification dynamics elucidates the early evolutionary stages of life on Earth, and its relationship to climatic and environmental changes. Environmentally volatile periods, such as the Silurian, make for excellent archives to study biological responses to change, and how such changes have influenced compositions of shallow marine invertebrate communities through time. Comparing paleoenvironmental and paleontological trends can highlight the optimal conditions that favor success of individual groups and faunal communities, as well as their responses to environmental stress, ultimately helping assess large-scale drivers of evolution and biodiversity. Furthermore, identifying boundaries of major lithofacies shifts that reflect environmental transitions provides a framework to track changes in paleoecologies and paleocommunities through time. The Appalachian Basin provides an excellent sedimentary archive for studying shifts in depositional environments through time based on its exceptional preservation of complete and nearly-complete depositional sequences (Ettensohn, 2006).

\section{Study Background}

An exposure of the Upper Silurian carbonate Bloomsburg and Mifflintown Formations of the northern Appalachian Basin in Bellwood, Pennsylvania (Figure 2) contains fossil assemblages that have not been described in literature, and stratigraphy that has only received cursory description. The study site is in Blair County of central Pennsylvania in the town of Bellwood. The outcrop is exposed along a hillside just off exit 42 on route 220 N (PA I-99) (Figure 1). No previous descriptions of the Bellwood locality stratigraphy and paleontology have 
been made. According to geologic maps published by the Pennsylvania Geological Survey, the exposed rock units correspond to the Mifflintown and Bloomsburg Formations. (Reference: maps). In central Pennsylvania, the Mifflintown and Bloomsburg Formations are not vertically consistent and are considered as undifferentiated due to their complex interfingering relationship, which represents deposition within a coastal margin subject to frequently fluctuating base level (Cotter, 1990; Hoskins, 1961).

During the middle Silurian, Pennsylvania was located roughly to the east of an epeiric sea and was separated from the Iapetus Ocean by the Taconic mountain range to the west (Cotter, 1990). The Appalachian foreland basin development persisted from the Middle Ordovician through the Permian, as a result of tectonic loading from a continuous series of orogenies along the Laurentian eastern continental margin (Ettensohn, 2008). The northern portion of the Appalachian foreland basin existed partially in central Pennsylvania, oriented roughly southwest to northeast (Ettensohn, 2008; Figure 2). Basin-fill units are thickest toward the east near the Taconic Mountains, where sediment was eroded and deposited within the basin system. Toward the Late Silurian, the basin-fill units transitioned from siliciclastic deposits of Taconic terrigenous influx to carbonate muds known as the Mifflintown Formation. These carbonate muds were deposited along the epeiric sea ramp to the center of the northern Appalachian foreland basin. Overlying the Mifflintown Formation in central Pennsylvania is the Bloomsburg Formation, a series of 'red beds' that have been interpreted as representing a variety of environments, from fluvial systems proximal to the Taconic clastic source, to a distal marginal marine delta-plain system (Driese et al, 1992; Hoskins, 1961). The Bloomsburg Formation spans parts of Pennsylvania (Figure 3), Virginia, Maryland, and West Virginia. The Mifflintown Formation is a more localized unit in central Pennsylvania, which turns into the McKenzie limestones in New York and the Williamsport member of the Wills Creek Formation across other parts of Pennsylvania (Hoskins, 1961). This study focuses on the undifferentiated Bloomsburg and Mifflintown Formations exposed in Blair County, Pennsylvania. The Bellwood locality represents the westernmost extent and thus carbonate-rich endmember of the Bloomsburg Formation, and is interfingered with the upper limestone and mudstone beds of the Mifflintown Formation. 


\section{Study Objectives}

This study provides the first formally written assessment of the Bellwood outcrop in central Pennsylvania, which includes detailed lithologic and paleontological descriptions based on outcrop, hand sample, and thin section observations, in addition to original paleoecological and paleoenvironmental interpretations. Silurian Appalachian Basin sequence stratigraphy records frequent small-scale fluctuations in relative sea level (Ettensohn, 2008), providing an excellent subject for studying the relationship between paleoenvironmental and paleoecological trends. This outcrop represents rocks that were deposited along the eastern coastal margin of the Silurian Interior Seaway.

This study evaluates shifts in shallow-marine invertebrate faunal communities and paleoecologies associated with changes in relative sea level during the Upper Silurian. Fundamental to reconstructing the paleoecology is understanding the environment of fossil deposition and how changes in these environments through space and time have had an impact on shallow marine fauna. Depositional settings will be interpreted through a facies analysis approach to reconstruct patterns in relative sea level and paleoecology. A sequence stratigraphic approach is applied to partition observed stratigraphic successions into discrete lithologic units based on distinct properties definitive of specific depositional environments or processes. Shifts in biofacies independent of changes in lithofacies provide a means for examining biological signals that drive changes in community composition (Holland and Patzkowsky, 2007). Combining analysis of sequence stratigraphy with paleobiology enables comparison of environmental and paleontological trends, a powerful approach for evaluating drivers of change in both paleoecology and paleocommunity through time. Understanding how changes in environment have helped shape paleoecological infrastructures within shallow marine carbonate environments is a focal point of this study.

How are the faunal composition of fossil communities changing through time? Are all shifts in fauna linked to shifts in depositional environment? Does the Bellwood outcrop sufficiently record any ecological turnover events? Are the observed shifts in depositional environment frequent enough to displace ecological communities? The Bellwood outcrop is one of the furthest western traces of the Bloomsburg Formation from the siliciclastic influx supplied by the eroding rock of the Taconic Mountains to the east. Given the location of the Bellwood outcrop in relation to the Bloomsburg type area, spatial variation in lithologic and textural 
characteristics are expected to be observed. These variations correspond to the relative distance of the depositional unit from the terrigenous source area. Lithologies observed in the Bellwood outcrop were expected to be carbonate-rich, with stratigraphy that reflects transitions between carbonate-siliciclastic depositional environments as a function of frequently fluctuating sea level. Presence of siliciclastic material would represent deposition proximal to shoreline or inlets that distribute sediment basin-ward. Changes in relative sea level were expected to be a dominant control of major paleoenvironmental and paleoecological shifts. Faunal communities were predicted to change based on water depth and energy levels.

\section{METHODS}

\section{Field work}

This study uses traditional stratigraphic paleobiologic methodologies. The dominance of weak mudstone along a steep hillside made this outcrop highly susceptible to weathering. The rock float that weathered downhill combined with vegetation coverage and stream run off channels presented challenges in finding decent bed exposures. Additionally, many of the exposed beds were laterally discontinuous and thus could not be traced for consistent distances across the outcrop. In effort to identify as many beds and in situ features as possible, areas were dug out along the strike of in situ beds for as far as the beds could be observed. Beds were also dug out to measure their true thicknesses. Despite the difficulties faced in the field, seven stratigraphic sections were measured and described to produce five stratigraphic profiles.

In the field, notes were taken based on observations of lithology, color (fresh and weathered), sedimentologic properties (grain types, grain sizes, grain distribution), sedimentary features, fossil content, fossil preservation quality, bedding geometry, measured bed thicknesses, bed exposure measurements, and associated lithologies. Photographs of outcrop and features of interest were taken as reference for later. Bulk rock and fossil samples were collected from beds of interest (Figure 4). Many rock samples were taken to supplement field notes of lithological, sedimentological, and paleontological features. The idea was that observed features unidentifiable in the field would be subject to further examination and research back in the lab. Most of the sampled beds were fossiliferous, so that fossil specimens can be observed and identified. It should be noted that most beds yielded some sort of body fossil, with the exception of the siliciclastic mudstones. The majority of sampled beds were carbonates, and siliciclastic 
mudstone units were generally avoided for sampling since they proved to be less informative out of stratigraphic context. In this study, it was particularly important to collect fossils found embedded within rock beds for two main reasons: 1) to resolve paleoecology by observing fossil fauna associations; and 2) to infer depositional setting based on lithofacies and sedimentary structures. Using a Silva Ranger compass, strike and dip measurements were taken on suitable bedding surfaces across the hillside exposure to identify any structural features that may obscure bedding orientation, such as overturned and parasitic folds. UTM coordinates were taken along with strike and dip, in addition to the bottom of each stratigraphic section and particular points of interest. The combination of stratigraphic, structural, and spatial data was later utilized to correlate and extrapolate rock beds between measured sections.

\section{$\underline{L a b \text { work }}$}

In the lab, bulk rock samples were further scrutinized to provide a full sedimentologic and paleontological description. Lithologies were named using the classification scheme for limestones by Dunham (1962). Sedimentologic properties and sedimentary features of each lithology were studied to interpret processes of deposition. Depositional environments were then interpreted based on unique sets of associated lithologies and the depositional settings they represent. The depositional environment is illustrated as a 'facies' in stratigraphy, defined as a collection of lithological associations and geologic properties that produce sequences characteristic of a particular environment or depositional setting. Geologic properties include bedding geometries, relative bed thicknesses, sedimentary structures, fossil content, and fossil preservation quality.

Five stratigraphic columns were constructed based on field observations and bed thickness measurements, which illustrate the changes in stratigraphy through time and provide a means for reconstructing evolution of depositional environments (Figures 5-10). Apparent dip pertains to the dip measurements taken in the field. Apparent thickness pertains to the measured length of bed exposure along the hill slope. This metric was used in areas where true bed thickness could not be measured due to being buried beneath soil, vegetation, and weathering rock. Apparent thickness and apparent dip measurements were used to determine the true thickness of sedimentary beds. Apparent dip was converted to true dip using the following equation: 


$$
\tan \delta=\frac{\tan \alpha}{\sin \beta}
$$

where $\alpha$ is apparent dip, $\beta$ is the angle between strike and apparent dip direction, and $\delta$ is true dip. Once true dip was calculated, the value was used to determine the true thickness of the bed, using the following equation:

$$
T=S * \cos (D)
$$

where $S$ is apparent thickness, $D$ is true dip, and $T$ is true thickness. These equations were taken from a geology course on the official U.S Navy website.

Fossil identification was based upon literature that describes early Paleozoic, shallow marine invertebrate fauna, centered around Silurian studies but also including those of Ordovician and Devonian paleontology (Sohrabi and Jin, 2012; Holland and Patzkowsky, 2007; Hajlasz, 1974; Cooper, 1973; Berdan, 1972). Taxonomic resolution was highest for the brachiopod specimens, the most abundant fossil group aside from the ostracods. This high resolution is in part owed to the relatively high taphonomy, as well as the distinct morphologies of different brachiopod groups present at the Bellwood locality. Analysis of sedimentological and paleontological properties of rock samples was supplemented by petrographic analysis. Rock samples were cut into slabs along planes with features of interest and sent out to be made into thin sections. Seven total thin sections were made; four $2 \times 4 \mathrm{~cm}$ thin sections and three $1 \times 2 \mathrm{~cm}$ thin sections. Thin sections were studied under both a Leica petrographic microscope and a Motic microscope. Petrography was significantly helpful for identifying fossil fragments and diagenetic features.

\section{RESULTS}

The Bellwood outcrop is dominated by compositionally variable mudstones susceptible to heavy weathering, forming stratigraphic successions that outcrop poorly along a steep hillside. The beds are generally oriented in a northeast direction, with strike measurements averaging between 40 and 50 degrees. In general, beds dip consistently in a northwestern direction, averaging around 44 to 50 degrees. Based on observation of geopedal features, such as channelfill features, gutter casts, and vertical burrows, the beds appear overturned. Therefore, based on the inclination of beds in relation to the angle of the hill slope, the beds get progressively older toward the top of the hill in the southeastern direction. Structural geologic maps of central 
Pennsylvania provided by the Pennsylvania Geologic Survey (PAGS) confirm the presence of overturned beds in this area.

The lower stratigraphic sections observed at the Bellwood locality are dominated by carbonate and siliciclastic mudstones with thin beds of skeletal packstone and wackestone. Fossils are more abundant and diverse relative to upper stratigraphic sections, dominated by open marine and reef building fauna. Mudstone lithologies become more siliciclastic-rich up-section. The carbonate beds become thicker up-section and interbeds are dominated by mixed calcareousnoncalcareous siliciclastic mudstones. Fossil content is sparse with low diversity relative to lower sections. Despite the numerous difficulties faced in the field, nine distinct lithologies were identified, and the stratigraphy at the Bellwood outcrop was broken up into four facies assignments based on the lithological associations.

\section{$\underline{\text { Lithologies }}$}

\section{L1: Bioclastic wackestone-packstone observations}

Bioclastic wackestone-packstones are medium gray and crystalline on fresh surfaces. The bright reddish orange colors and differential weathering pattern make this lithology visually distinctive (Figure 11a-b). Composition consists of greater than 50\% coarse skeletal grains, with a mix of lime mud, intergranular, and intragranular calcite cement (Figure 12). Beds are thin and range 1-3 cm in thickness. Bedding surfaces exhibit a mottled texture, a sign of bioturbation. Bedding planes are tabular to nodular, and at times amalgamated where associated siliciclastic mudstone interbeds have been eroded. Clay rip-up clasts are common. Fossil diversity and abundance is relatively high and includes a mix of whole-valve fossils as well as fragments. Fossil fauna is dominated by Strophomenid brachiopods Rafinesquina and Sowerbyella (Figure 11E-G). Crinoid fragments including pieces of columns and ossicles are also abundant. Less common fossil fauna consist of the Rhynchonellid brachiopods Lepidocyclus and Eocelia, Trepostome and Fenestrate bryozoa, and ostracods. Most fauna were identified from fragments, with articulate brachiopods exhibiting the highest preservation quality. Forms observed as fragments included trilobite cranidium fragments (Figure 12b), bivalves, unidentified worm-like organisms, foraminifera, and potentially corals and gastropods. Diagenetic features observed in thin section include calcite cement growth, stylolite's, and sutures (Figure 12). Mineral replacement is commonly observed, in which iron-rich minerals, such as pyrite, replace skeletal grains, most commonly articulate brachiopod specimens. Bioclastic wackestone-packstone is 
observed in association with green-gray siliciclastic mudstone, as well as mottled, nodularbedded packstone.

\section{L1: Bioclastic wackestone-packstone interpretations}

Evidence of reworking in beds of bioclastic wackestone-packstone includes rip-up clay clasts, moderately poorly sorted textures, and mixed-habitat fauna observed in fossil assemblages. The fossiliferous assemblages observed are characteristic of storm reworking, based on co-occurrence of fossil fauna from different sub-environments within individual beds. The diverse suite of fossil fauna observed in these beds include representatives from shallow reefs (corals), mud flats (Rafinesquina), and potentially lagoons (bivalves, gastropods). The relative abundance and completeness of the Strophomenids Rafinesquina and Sowerbyella and crinoid fragments indicate these faunas were deposited near their living environment. Strophomenid brachiopods such as Sowerbyella have been observed in deeper-water faunal assemblages relative to more robust-shelled brachiopods such as Hebertella and Platystrophia (Hanford, 1985). Presence of styolites and sutures in wackestone-packstone beds are evidence of compaction associated with dissolution of carbonate minerals. Evidence of grain transport in these beds are the disarticulation and fragmentation of fossils, as well as the moderately-poorly sorted nature of the constituent grains. Bioclastic wackestone-packstones are interpreted as storm beds that were deposited below storm wave base in open ramp environments.

\section{L2: Green-gray siliciclastic mudstone observations}

Intervals of olive green to gray siliciclastic mudstones occur as meter-scale successions with thin interbeds of bioclastic wackestone-packstone. This mudstone is argillaceous and generally non-calcareous. Fresh mudstone surfaces weather a deeper olive green or rusty orange color. Bedding planes are typically thin and fissile and less commonly tabular, exhibiting conchoidal and irregular textures on breakage surfaces. This lithology is void of body fossils, however, trace fossil occurrences include Planolites.

\section{L2: Green-gray siliciclastic mudstone interpretations}

Thin, fissile layers of mudstone indicate deposition within a calm, low-energy environment conducive for suspension settling of fine clay particles. The green coloration of this mudstone is indicative of reduction. The siliciclastic composition, bioturbation evidenced by Planolites, and the general lack of body fossils suggests deposition in a protected, low energy environment. 


\section{L3: Mottled nodular packstone observations}

The nodular-bedded, mottled packstone lithology is comprised of about 50\% silt-sized carbonate grains and cement, with the remainder consisting of brown silts and clays, very fine to fine white quartz sand grains, and uncommon skeletal material. This lithology exhibits light gray to brownish gray colors on fresh surfaces, weathering a chalky brown to orange (Figure 13). Weathered surfaces exhibit a shiny luster or sheen, with faint, thin cracks, interpreted as pedogenic slickensides. Beds are wavy to nodular, producing a hummocky bedding geometry. The beds become lenticular in association with fossiliferous mudstone-wackestone beds (L4). Internal bedding structures include flaser to wavy laminae, planar laminations, and wave ripplelaminae. Laminations alternate between white sandy carbonate and slightly thicker brown silty/muddy layers. Where observed, fossil fauna is dominated by Strophomenid and Rhynchonellid brachiopods, as well as crinoid fragments. Bed bases exhibit a mottled texture which commonly includes Chondrites and Zoophycos traces (Figure 14). Planolites feeding-type trace fossils are observed on some bedding surfaces associated with green-gray siliciclastic mudstone. This packstone is closely associated with a brown, calcareous Chondrites-bearing silty mudstone, which forms as interbeds between the thin bedded carbonate packestones. Often, the brown calcareous mudstone appears as shaly partings on packstone bases and surfaces.

\section{L3: Mottled nodular packstone interpretations}

The nodular to lenticular bedding geometry is characteristic of tidal deposits and possibly represent channel-fill or channel avulsion patterns. The internal bedding structures of wavy to flaser bedding resemble intertidal deposits associated with tidal cycles (Shin, 1983). However, these structures may also represent sandy carbonate couplets which are constituents of tempestite sequences (Burchette and Wright, 1992). The heavily mottled surfaces indicate high amounts of bioturbation, typical in finer-grained storm deposit interbeds (Cotter, 1990; Holland and Patzkowsky, 2012). The relative lack of body fossils and occurrence of Chondrites at brown silty bases of some packestone beds indicates stressed conditions relating to low oxygen in a lowenergy environment (Sumrall et al, 2009; Cotter, 1990), likely corresponding to restricted environments such as a lagoon or tidal flat environment. Based on a mixed siliciclastic-carbonate composition, lenticular bedding geometry, and well-developed Chondrites trace fossils, the mottled nodular packstone lithology is interpreted as reworked tidal flat deposits.

\section{L4: Fossiliferous mudstone-wackestone observations}


Fossiliferous mudstones and wackestones are indurated and highly friable, producing a distinctive texture (Figure 15). Color seems to vary according to composition: argillaceous mudstones are a darker gray color, and fossiliferous, calcareous mudstones are a lighter, dustier gray. This lithology is characterized by its exceptional preservation of shelly fossil fauna, including whole articulate brachiopods and mollusks (Figure 15). The suite of fossils reflect an open marine fauna, including Atrypa and Rhynchonellid brachiopods, Hebertella, orthocerid nautiloids, hormotomid gastropods, tentaculitids, and ostracods. Fossiliferous mudstone and wackestone are observed in association with nodular-bedded mottled packstones, peloidal grainstones, and brown calcareous mudstone.

\section{L4: Fossiliferous mudstone-wackestone interpretations}

Exceptional preservation of shelly fauna in an argillaceous and calcareous mudstonewackestone deposit suggests a low-energy, anoxic environment, indicating deposition in a subtidal setting beneath fair weather wave base, such as the middle-outer ramp, offshore, or basinal lagoon environments. Based on its association with lithologies containing subtidal to intertidal features, as well as occurrence of open marine fauna mixed with more environmentally tolerant forms (tentaculitids and gastropods), an open, near-shore subtidal depositional environment is favored for these fossiliferous mudstones and wackestones.

\section{L5: Laminated peloidal grainstone observations}

Laminated peloidal grainstone is composed of about 50\% silt-sized peloids, very fine to fine quartz sand grains, and calcite cement, and 50\% skeletal grains (Figures 16 and 17). Fresh surfaces are a medium gray color, weathering a dusty reddish brown that often accentuates the laminations as rusty orange bands. Beds are thin $(2-4 \mathrm{~cm})$ to laminated with planar to tabular bedding geometries. Laminations are planar to wavy, illustrating alternation between light colored sandy carbonates and brown muddy-peloidal layers. A major distinguishing feature of this lithology is the mass accumulation of ostracod valve fossils that are commonly observed on bedding bases. The size of ostracod valves averages about 1-2 $\mathrm{mm}$ in length. In many layers, ostracods are so abundant that they resemble a 'sesame seed' texture (Figure 16). A wide range of fossil fauna in addition to ostracods are observed in certain lamainated layers of peloidal grainstone. Ostracods, as well gastropods and tentaculitids, are observed as virtually complete or partially complete fossil specimens with high relative abundances. Less commonly, fossiliferous assemblages are dominated by either tentaculitids or gastropods. Tentaculitid-dominated 
assemblages exhibit a strong axial alignment of specimens. Fossil assemblages may also include fragments of numerous faunal groups, such as tabulate corals, bryozoans, sponges, crinoids, Rhynchonellid brachiopods, foraminifera, trilobites, and potentially extremely rare fish scales. In thin section, palynomorphs are also observed.

\section{L5: Laminated peloidal grainstone interpretations}

Presence of planar to wavy laminations is evidence of deposition at shallow depths corresponding to above fair-weather wave base. White sandy laminae are interpreted as skeletal shoal deposits, and brown peloidal mud layers represent tidal flat sediment. Peloids are common components in lagoonal, shoreface, and tidal flat deposits (Waziretal, 2010) Peloids within tidal flat deposits have been observed as small-scale cross-bedded laminations of sand-sized mud pellets (Shin, 1983). Additionally, these sequences of planar to wavy-laminated sands and muds with mm-scale skeletal-rich horizons bear resemblance to structures that have been observed in tidal rhythmites of the intertidal zone (Tessier, 1992). The mixing of sandy skeletal shoal and mud flat laminae are typical depositional units in tidal flat environments (Shin, 1983). Laminations may represent tidal cyclicity within a subtidal to intertidal tidal flat. The observed laminated peloidal grainstones and associated brown calcareous mudstones lithologies are similar to tidal channel deposits described by Anya and Trop, 2019, which the authors described as biomicrite to biosparite facies.

The high diversity and fragmented nature of fossil fauna suggest reworking and transport of skeletal grains from various depositional settings. Specifically, the mixing of shelly and benthic-dwelling fossil fauna observed is typically characteristic of shallow, near-shore settings such as the shoreface, beach, or intertidal zones (Kreisa, 1981). Skeletal peloidal grainstones have been documented as representing shallower-water deposition at depths above fair-weather wave base, such as inner carbonate ramp environments or inner platform lagoons (Waziretal et al, 2010). The association of well-preserved ostracods, gastropods, and tentaculitids with fragments of open marine fossil fauna suggest the skeletal material of these deposits were sourced from multiple environments, which were likely adjacent. The low diversity but high abundance of individuals is characteristic of stressful environmental conditions. These fossil groups are known to be tolerant of a relatively wide range of environmental conditions relative to open marine fauna (Hajlaz, 1974). Strong alignment of tentaculitid fossils indicate there was one dominate, high-energy flow direction. Presence of palynomorphs indicates incorporation of plant 
material (Johnson, 1985), further suggesting deposition in a shallow, near-shore environment. Similar mud and sand laminae have also been documented as subtidal 'tempestite couplets' (Burchette and Wright, 1992). The alternating shoal and mud flat planar to wavy laminae indicate deposition in the tidal zone. Based on evidence of deposition in a high-energy environment influenced by tidal and storm processes, the laminated peloidal grainstones are interpreted as representing shoreface deposits, corresponding to subtidal inner ramp settings.

\section{L6: Recrystallized skeletal packstone observations}

Beds of recrystallized skeletal packstone are a combination of coarse skeletal grains and calcite cement, with lesser components of peloids and carbonate mud (Figure 18a-f). Grains are relatively poorly-sorted, with a mix of sand-sized grains, coarse skeletal grains, and gravel-sized bioclasts. Fresh surfaces are medium gray and highly recrystallized. These beds typically weather a dusty light brown color. Beds are thin and tabular to rarely heterolithic, with thicknesses ranging 2-6 cm. Internal layering is produced by alignment of articulate brachiopod shells, generally oriented convex-up (Figure 18g). In some stratigraphic sections, recrystallized skeletal packstone is amalgamated with laminated peloidal grainstones and brown calcareous mudstones. These amalgamated beds have irregular thicknesses, producing complex or composite bedding relationships. The diagenetic features observed in these beds characterize this lithology. In outcrop, calcite-filled veins and recrystallized grains are easily observable. In thin section, diagenetic features are more recognizable and include stylolite's and sutured grain contacts, interlocking crystal mosaics, drusy calcite cement, and potential anhydrite nodules (Figures 18-19). Iron minerals pyrite and hematite are observed as replacing brachiopod fossils and other carbonate grains. Observed fossil fauna are dominated by articulate brachiopods and crinoid fragments, mostly sections of columns and individual ossicles. Common brachiopods are the Rhynchonellids such as Eocelia and Stegerhynchus, and Orthids such as the genuses Dalmanella and Hebertella. Skeletal fragments are abundant, but often unidentifiable. In rare concentrations, the following fossil fauna have been observed as fragments: bryozoans, sponges, corals, foraminifera, trilobites, ostracods, and gastropods, of the fossil forms that could be identified. Cornulites, a worm-like organism, is observed in rare abundancies in few fossil assemblages, but is typically well-preserved. 


\section{L6: Recrystallized bioclastic packstone interpretations}

The massive, poorly sorted texture suggests instantaneous deposition. The layers of aligned brachiopod shells have been observed in distal and proximal ramp tempestite deposits (Yao et al, 2016). A more proximal ramp setting is the preferred interpretation, based on the generally convex-up oriented disarticulated brachiopod shells in a dominantly calcite cement composition that lacks lime mud. Pyrite replacement suggests deposition within a semi-restricted environment. Stylolite's and sutures indicate surfaces where pressure dissolution has removed carbonate material. Meteroic diagenesis is characteristic of subaerial exposure during sea level lowstands, represented by dissolution features, precipitation of anhydrite, and drusy and blocky calcite cement (Rahimpour-Bonab et al, 2010). However, features of subaerial exposure in recrystallized bioclastic packstone beds are not convincing. The presence of meteroic diagenetic features may be sourced from shallower water deposits, which were reworked during periods of intense storm activity and deposited downslope into deeper ramp settings. Based on high concentration of calcite cement, diagenetic alteration (recrystallization and dissolution), and association with subtidal shoreface deposits (L5), beds of recrystallized skeletal packstone are interpreted as reworked inner ramp reef deposits that were redeposited in the inner to middle ramp zone during storm activity.

\section{L7: Intraclastic conglomerate and detrital carbonate observations}

This lithology is characterized by poorly-sorted sands and gravels, micritic intraclasts, few skeletal grains, and flattened-pebble clasts, although relative concentration of these grain types vary by bed (Figure 20). Beds are on average 10-15 cm thick with heterolithic bedding geometries. Intraclastic flat-pebbled carbonate conglomerate beds weather a red to maroon color.

Detrital carbonate beds are similar in composition to intraclastic beds, however beds are typically finer-grained containing a higher concentration of medium to coarse quartz sand, angular granules, and micritic intraclasts, with a general lack of flat pebbles (Figure 20, C-F). Detrital carbonate beds have a 'chaotic', poorly sorted like intraclastic beds, except they flat pebbles. Sand and mud couplets are observed as heterolites, cross-bedded with the detrital carbonates. Sometimes these heterolites appear as cross-stratified sands and muds that had filled in channel scours, forming gutter casts. Channelized gutter casts, scouring, and flute casts are distinctive features of this lithology. Presence of fossils are generally sparse, but where observed they are typically ambiguous fragments or heavily abraded. Isolated stromatolites and crinoid fragments 
are observed on red weathered muddy intervals directly beneath flat-pebble zones. Isolated stromatolites appear as circular to cylindrical hollows that resemble hive-like structures. Fragments of Fenestrate bryozoans, ostracods, and potential bivalves can be observed incorporated within detrital conglomerate beds.

\section{L7: Intraclastic conglomerate and detrital carbonate interpretations}

The heterolithic cross-stratification (HCS), buckled bedding, and hummocky bedforms evidence scouring and erosional processes on depositional surfaces by wave energy. Based on the sculpted, scoured, and heterolithic nature of beds, this lithology seems to reflect channel influence, which correspond to intertidal or subtidal channel activity. Presence of fluted surfaces and gutter casts suggest subaquaeous channels may have influenced depositional processes. The association of isolated stromatolites and crinoid fragments on some surfaces represents hardgrounds, which commonly form on the top of storm rhythmites (Swett and Smit, 1972). Nearly instantaneous deposition of flat-pebble conglomerates onto supratidal flats due to storm events has been documented in other deposits (Shin, 1983). Intraclasts are also known from subtidal channel deposits as part of the basal channel lag (Shin, 1983). A subtidal depositional environment is favored, supported by the conglomerates close association with dark brown to black siliciclastic mudstones and cherty micrites.

\section{L8: Massive microcrystalline carbonate observations}

The massive microcrystalline carbonate lithology is resistant and dark gray, typically occurring in 10-15 cm thick beds (Figure 21). This lithology ranges from massive and finegrained to crystalline with faint laminations. Chert is present as nodular to lenticular beds. Characteristic of this lithology is the micritic to almost cherty texture, as well as the smoothly sculpted pattern on weathered surfaces. In addition to calcite veins, small vugs $(\sim 2-10 \mathrm{~cm})$ are a commonly observed dissolution feature. Reduction spots and calcite cement growth are also observed, although seemingly less common. Massive microcrystalline carbonate is apparently void of body fossils, although bioturbation is evidenced in some beds where vertical burrows penetrate down from surfaces in high concentrations. Trace fossils Ruscophycus and Cruziana were commonly observed on bedding surfaces, and Scoyenia traces were observed less commonly on bed bases associated with brown calcareous mudstone (L9). Microcrystalline carbonate beds are interbedded with brown calcareous mudstones, which often form as shaly partings on surfaces and bases of the massive carbonate beds. 


\section{L8: Massive microcrystalline carbonate interpretations}

Microcrystalline carbonate typically represents slow deposition within low-energy, protected deep or shallow water environments, such as tidal flats, restricted lagoons or epeiric seas, and offshore (Anya and Trop, 2019; Vrazo, 2014; Swett and Smit, 1972). The presence of Cruziana ichnogenera and calcite veins further indicate deposition in the sublittoral zone, specifically in protected areas of the continental shelf (Baniak et al, ). Based on the micritic composition, sublittoral ichnogenera, cherty nodules, calcite-filled veins and vugs, vertical burrowing, and faint algal laminations, these micrite beds are interpreted as reflecting deposition in shallower waters of the intertidal zone or tidal mudflats (Anya and Trop, 2019; Swett and Smit, 1972). General lack of body fossils and presence of feeding-trace type ichnogenera Cruziana and Ruscophycus suggest depositional settings in an environment unlivable for most organisms.

The massive microcrystalline carbonate beds observed in Bellwood closely resembles micritic limestones described from the Upper Silurian Tonoloway Formation in Pennsylvania, which have been interpreted as arid, restricted lagoonal-tidal flat deposits (Vrazo, 2014). The Tonoloway Formation is distinct in that it contains cubic halite precipitates, evaporite minerals, and obvious desiccation features such as mudcracks. The absence of such features in the micrites observed at the Bellwood locality suggest the tidal flat system evolved from somewhat temperate conditions to more arid, restricted conditions between deposition of Bellwood micrites and Tonoloway micrites, respectively. This temporal change to more sabkha-like settings suggests the region experienced a relative sea level regression.

\section{L9: Brown calcareous mudstone observations}

This lithology is reddish to medium brown in color, weathering a dark chocolate brown. Composition is dominated by silt-sized siliciclastic grains, with minor concentrations of carbonate and skeletal grains. The mudstone is weakly to moderately calcareous, with some thin layers yielding abundant ostracod or bivalve fossils. This lithology was deposited as $2.5-5 \mathrm{~cm}$ thick interbeds between massive microcrystalline carbonate beds (Figure 21). Beds are typically planar to cross-laminated and fissile. Occurrence of more-resistant, wavy to lenticular coarsergrained beds is less commonly observed in thicker interbeds of planar-bedded mudstone. Such lenses may be micritic and fossiliferous or comprised of laminated sands. In rare occurrences, flute casts have been observed on bed bases. Where fossils occur, diversity is low, often 
consisting of one or two abundant taxa. Faunas typically consist of either bivalves such as the oyster Leiopteria, or mass accumulations of tiny ostracods. A single body fragment of a Eurypterid, a tergite, was observed within darker gray, argillaceous mudstone layers. Fragments of eurypterids are rare to the Bloomsburg Formation, with the only other known occurrence being tergite fragments at the Mt. Union, PA locality (Hoskins, 1962). Potential traces of the inarticulate brachiopod Lingula, represented by Scoyenia trace fossils, are observed in some beds, though not as commonly.

\section{L9: Brown calcareous mudstone interpretations}

Presence of the oyster Leiopteria suggests deposition in brackish waters. Potential presence of Lingula is also consistent with a brackish water environment. The low faunal diversity but high abundance is characteristic of tidal flat and protected lagoonal environments. The less common wavy to lenticular beds are interpreted as channel-form gutters, which represent surfaces of shallower water deposits that were scoured out by storm waves and transported downslope as cohesive lenticular packages.

\section{DISCUSSION}

$\underline{\text { Facies }}$

\section{F1: Distal ramp storm deposits}

The deeper shelf facies is characterized by thin-bedded carbonate wackestone-packstones within green colored siliciclastic mud-dominated successions. The lithological associations produce sequences characteristic of storm deposits, or tempestites, that occur in distal areas of a muddy, low-gradient carbonate ramp (Cotter, 1990; Figures 6-7). Other definitive features of this facies include the distinctive weathering and carbonate dissolution textures. Dominance of siliciclastic mudstone, relatively thin storm beds, and general lack of sedimentary structures indicates deposition at depths below storm wave base, potentially corresponding to distal middleouter ramp environments, or deep lagoons. The dominance of articulate brachiopod and crinoid fauna in fossiliferous beds suggests normal marine salinities, thus supporting the argument for deposition in distal ramp areas. Intervals of siliciclastic mudstone represent deposition during periods of fair-weather. Occurrence of worm-like organisms evidenced by Planolites within muddy interbeds suggest deposition in a relatively low-energy, oxygen-rich environment that allowed worm-like organisms to burrow (Swett and Smit, 1972). Reworked beds include elements of shallower environments, such as the reef crest and upper slope. Beds of bioclastic 
wackestone-packstone are indicative of a more basin-ward middle ramp setting, evidenced by higher concentration of mud, lack of sand, generally massive (structureless) beds, and dominance of muddy substrate fauna, such as Rafinesquina. Similar storm sequences have been observed within deep-subtidal environments of the Upper Ordovician Cincinnatian Series (Holland and Patzkowsky, 2007), where beds of skeletal packstone, grainstone, and calcareous siltstone beds are the dominant lithofacies.

Nodular bedded mottled packstones (L3) are less commonly directly associated with the bioclastic wackestone-packstone lithologies within this sequence and are thus interpreted as representing beds from an adjacent, shallower depositional setting. Presence of nodular-bedded packstones in deeper ramp deposits indicate a shallowing-upward of environments. These packstones are interpreted as reworked muddy subtidal deposits transported downslope during storm events. Lenticular packstone beds are interpreted as gutter casts that were scoured out from deposits of laminated peloidal grainstone in the shallower inner ramp flat environments. This might explain the why the mottled packstones internal bedding structures contain tidally influenced features (Shin, 1983).

F2: Open marine or subtidal lagoon

This facies is comprised of mottled nodular packstone (L3), fossiliferous mudstonewackestone (L4), peloidal grainstone (L5), and brown calcareous mudstone (L9) (Figures 6-7). This lithological association seems to be localized to a small area of the Bellwood exposure. Fossiliferous mudstone-wackestone dominates the sequence. Based on exceptional preservation of shelly marine fauna and mix of calcareous and carbonate mudstones, deposition in an open shelf or subtidal lagoon environment. Localized deposits of peloidal grainstone represent subtidal flat environments, yielding separate beds of abundant tentaculitids, gastropods, and ostracods. Chondrites and Zoophycos trace fossils observable on mottled surfaces of brown calcareous mudstone suggest deposition in an environment depleted of oxygen (Anya and Trop, 2019; Cotter, 1990), consistent with a basinal lagoon environmental interpretation. Although Chondrites is known from an array of depositional settings and water depths from deep subtidal (Anya and Trop, 2019) to intertidal, the association of these Chondrites-bearing mudstonepackstones with planar to wavy laminated peloidal grainstones provides a more compelling argument for deposition above fair weather wave base. 


\section{F3: Proximal ramp shoreface storm deposits}

As a function of decreasing depth through time, the bioclastic wackestone-packstone lithologies (L1) grade up into recrystallized bioclastic packstones (L6), and the mottled nodularbedded packstones (L3) grade up into the more regular bedded laminated peloidal grainstones (L5). Additionally, mudstone interbeds become coarser with increasing silt content, calcareous, and brown in color. This lithological association produces sequences that appear influenced by either tidal or storm energy.

Skeletal peloidal packstone lithologies are known from middle ramp environments of early Cretaceous carbonate deposits in the Middle East (Waziretal, 2010). In the Bellwood outcrop, mixed noncalcareous and calcareous mudstones (L9), laminated peloidal grainstones (L5), and recrystallized bioclastic packstones (L6) produce sequences indicative of storm deposition below fair-weather wave base (Figure 6). Such sequences are characterized by general fining-upward trends. Peloidal and sandy laminated grainstones of the shoreface sediments overlie the recrystallized bioclastic packstone reworked ramp deposits. The grainstones and packstones lithologies most commonly occur as discrete beds, however, a few amalgamated beds have been observed. Such beds represent sections with missing layers due to erosion and bioturbation, as evidenced by extensive vertical burrowing. Amalgamation is characterized by complex or composite bedding relationships, indicative of termination and sculpting associated with storm energy (Cotter, 1990). This relationship also exists between the packstones and fissile brown mudstones where grainstone interbeds are absent due to erosion.

During peak storm activity, rapid deposition of coarse-grained skeletal material under upper plane bed conditions produced massively bedded recrystallized bioclastic packstones and shelly lags. Deposition of massive packstone beds created hard surfaces for fauna to reestablish on known as firmgrounds, based on presence of crinoids, articulate brachiopods, and Cruziana on bedding surfaces. As storm energy waned, finer sediment and skeletal material from more proximal reef shoal and tidal flat environments of the shoreface were deposited by ebb-tide flows as planar to wavy-laminated peloidal grainstones. Deposition of the fissile mixed mudstones resumed once storm energy subsided. Fair weather periods promoted biological activities such as burrowing, evidenced by mottled bedding surfaces and vertical burrows that penetrate underlying peloidal grainstones, obscuring the laminations (Figure 19a). Bioturbated deposits are interpreted as deposited below fair-weather wave base, based on association with deeper ramp deposits. 
Additionally, the mixing of siliciclastic and calcareous muds indicates deposition proximal to a siliciclastic source area, which potentially corresponds to a delta-front environment (Tirsgaard, 1992).

\section{F4: Intertidal: delta-front}

The lithological associations of intraclastic conglomerates and detrital carbonates (L7), massive micrite (L8), brown calcareous mudstones (L9), and dark-colored siliciclastic mudstones are interpreted as a series of storm rhythmites deposited in the shallow subtidal to intertidal zone of a prograding delta-front (Figures 8-10) Intraclastic conglomerate beds with channel-form features such as gutter casts and flute marks make up the base of sequences and are interbedded with black siliciclastic mudstones. Detrital carbonate beds exhibit heterolithic bedding in the middle and upper parts of sequences. During major storm events, sediments sourced from supratidal and intertidal were reworked and redeposited as intraclastic conglomerates in deeper settings along the ramp. Occurrence of intraclasts is common in intertidal settings (Shin, 1983). Flat-pebbled conglomerates represent ripped up and reworked clasts of rock from tidal flats, deposited in settings as shallow as the supratidal zone. Based on heterolithic bedding, poorlysorted nature, and lack of marine fossils, intraclastic conglomerate is interpreted as representing supratidal to intertidal channel-fill deposits.

This interpretation is based upon the very poorly sorted texture and conglomeratic nature of these intraclast beds. High energy conditions would be required to move flat pebbles. Bioturbation evidenced by mottled shaly surfaces are characteristic of storm interbeds, representing periods of low-energy between storm events. Going up sequence, carbonate beds become thicker and siliciclastic interbeds become thinner and lighter in color, and eventually more calcareous. Sequences are capped by medium-bedded hummocky cross-stratified intraclastic and detrital carbonate beds. Surfaces represent firmgrounds based on presence of isolated stromatolites that grew on the brown to red silty shales.

The dark-colored siliciclastic mudstones and micritic limestones hint at deposition in relatively low-energy environments. Interbeds of brown calcareous mudstone represent deposition within intertidal/deltaic channels. The occurrence of brackish water-tolerant taxa, Lingula and Leiopteria, within brown calcareous mudstone interbeds suggests a zone of seawater-freshwater mixing, potentially corresponding to an intertidal or lower delta plain environment. This is supported by presence of Scoyenia trace fossils, representative of the 
inarticulate brachiopod, Lingula, a form known to tolerate brackish water. These fine-grained lithologic sequences are similar to the restricted lagoonal and tidal flat facies of the upper Silurian Tonoloway Formation of the Appalachian basin, which are described as thin to medium bedded micritic limestones with fissile, calcareous shale interbeds and minor components of grainstones and packstones (Vrazo et al, 2014). The main difference between Bellwood micrite facies and Tonoloway micrite facies is that the Tonoloway Formation exhibits more evidence of sabkha-like, restricted environments, such as cubic halite casts and subaerial exposure, features that are lacking in the Bellwood micrites. Sequences including intraclastic flat pebble conglomerates are similar to depositional models for carbonate-siliciclastic transitional zones (Tirsgaard, 1992).

The uppermost observed stratigraphy at the Bellwood locality is characterized by sequences of brown calcareous mudstones and massive micrites, and the absence of intraclastic beds. These deposits suggest quiet deposition in placid, semi-protected settings, such as deep subtidal flats (Figures 9-10). The dark brown to black color of siliciclastic mudstones suggests low oxygen conditions and incorporation of organic material. The lack of bioturbation further reflects anoxic conditions, typical in intertidal zones and anoxic basinal waters (Cotter, 1990). Such mudstones may represent the fine anoxic pro-delta muds of the delta-front. The high abundance and low diversity of fossil fauna observed within brown mudstone interbeds is typical of tidal flats (Shin, 1983). Presence of bivalves and inarticulate brachiopod Lingula supports the notion for a brackish water depositional environment. The wavy, heterolithic bedding style of brown calcareous mudstones and massive micrites is characteristic of intertidal deposition (Shin, 1983).

\section{Depositional System}

The stratigraphic successions observed at the Bellwood outcrop in central Pennsylvania are interpreted as representing shallow marine environments within a muddy, low-gradient carbonate ramp system. This depositional system was located along the low-energy coastline of a shallow interior seaway that was periodically impacted by major storm events. During the late Silurian, wave energy was relatively calm due to closure of the Iapetus sea, which blocked trade winds and redirected hurricanes (Ettensohn, 2006; Driese et al, 1992). The association and dominance of mixed carbonate, calcareous, and siliciclastic mudstones indicate deposition in an environment proximal to multiple sediment sources, suggesting a transitional, nearshore 
environment (Tirsgaard, 1992). No major unconformities that signified a slope break were observed, and facies boundaries were gradual. Storms were a major depositional process that helped maintain buildup of the carbonate ramp by reworking and redistributing sedimentary deposits. The prevalence of storm deposits observed in this outcrop suggest that most of the depositional environments correspond to water depths beneath fair-weather wave base (Burchette and Wright, 1992). Siliciclastic influx was supplied by a prograding delta, which was likely intersected by many intertidal to subtidal channels. Carbonate beds become thicker up-section, reflecting a shallowing-upward pattern. Coarsening-upward of carbonate lithologies is characteristic of middle ramp storm deposits in the Mifflintown Formation (Cotter, 1990), consistent with interpretations of the Bellwood outcrop.

The stratigraphically older sections of the Bellwood outcrop were dominated by tidal and storm depositional processes, represented by facies 1-6. During periods of fair weather in subtidal settings above normal wave base, deposition was influenced by tidal energy, represented by alternating planar to wavy laminations of skeletal shoals and peloidal mudflat sediment. Planar to ripple-bedded sands and muds, with mm-scale skeletal-rich horizons, or 'tongues' have been observed in upper intertidal zone tidal rhythmites (Tessier, 1992). A change in depositional system is observed in stratigraphically younger sections, represented by L7-9. The occurrence of intraclastic conglomerate beds mark the transition from a muddy carbonate ramp dominated by open marine fauna to a siliciclastic-dominated lower delta plain complex. Based on the general shallowing-upward trend from carbonate-rich to siliciclastic-rich depositional environments, this depositional system change may be the result of increased influx of siliciclastic material, which would have enabled progradation of a coastal delta. This observation may correspond to a period of sea level decline that occurred during the middle to late Silurian, which is represented in the geologic record by the development of the Salinic unconformity (Ettensohn, 2006). However, this change from predominantly subtidal ramp environments to delta-dominated slope may be attributed to lateral migration of the delta along the interior seaway coast, due to fluvial channel avulsion occurring on land that would ultimately influence sediment transport routes. 


\section{Paleoecology}

Paleoecology was assessed at the community level. Communities exhibited a range of salinities, from open marine to brackish. The most taxonomic variation among depositional settings is observed in the open marine communities.

Open marine: deep ramp communities

Middle to outer ramp communities are dominated by articulate brachiopods and crinoids. Organisms of this group are primarily epifaunal suspension feeders, and comprise deeper-water reef-building communities. This paleoecology is characterized by organisms that prefer deeper, cooler water, suggested by the absence of tabulate corals and other light-dependent organisms. The most ecological variability is observed within the brachiopod group. Rhynchonellid brachiopods live similarly to crinoids, attached to a hard substrate. Strophomenids have a more unique life mode, living unattached to a substrate and partially buried beneath the sediment (Holland and Patzkowsky, 2007). Beds dominated by well-preserved Strophomenid brachiopods, Rafinesquina and Sowerbyella, support the argument for a deeper water setting, given their preference for soft, muddy substrates (Prothero). Strophomenid brachiopods such as Sowerbyella have been observed in deeper-water faunal assemblages relative to more robust-shelled brachiopods such as Hebertella and Platystrophia (Hanford, 1985). The trace fossil Zoophycos occurs on some bedding surfaces, which are known strictly from deeper-water habitats during the Silurian (Donovan ed., 1993). Crinoids, as well at the Rhynchonellid genuses Stegerhynchus, Lepidocyclus, and Eocelia, are stationary organisms known to prefer harder substrates. This suggests these communities possibly lived somewhere in the middle ramp zone and colonized the harder substrates that were products of reworking and transport of coarser-grained material during storms. Although crinoid fragments could not be identified, at least two different crinoid forms have been observed, based on differences in ossicles: star-shaped vs circular ossicles. Such faunal assemblages are observed in bioclastic wackestone-packstone beds with a diversity of other open marine fossil fragments, including trilobites, bryozoans, and bivalves. The fossil fragments are interpreted as having been reworked from shallower depths and transported downslope. The strophomenid fauna is interpreted as representing deeper depths relative to the other middle ramp fauna. Rare but well-preserved specimens of the worm-like Cornulites potentially has some association with the deeper-water brachiopod, Rafinesquina. This is supported by known occurrences of Cornulites being associated with such forms (Morris, 1971). 
However, in the case of this study, it is unknown whether these specimens are biologically associated, or just coincidently inhabit similar environmental settings, since Cornulites specimens were not observed encrusted on any fossil taxa.

\section{Open marine: open lagoon communities}

Another open marine community is characterized by exceptionally preserved shelly fauna. The preservation quality suggests a calm, lower-energy environment corresponding to outer ramp-offshore environments or an open subtidal lagoon, further supported by the finergrained lithologies these communities were observed in (L4). The paleoecology is characterized by stationary epifauna, and mobile organisms, both benthic and pelagic. Communities are dominated by brachiopods with smaller hinge-lines, namely the abundant Spiriferid Atrypa. Hebertella is also present. In addition to brachiopods, mollusks including the nektonic orthocerid nautiloids, benthic gastropods, and small bivalves are present. Molluskan diversity hits its peak in this fauna. The occurrence of orthoceras is restricted to the fossiliferous mudstone lithofacies, and orthoceras' association with gastropods and the abundant Atrypa brachiopods further suggest a muddy, low-energy living environment. Small, articulate brachiopods, namely the Spiriferid Atrypa, are extremely abundant and their colonies dominate this faunal community (Figure 15). This community consists of invertebrate fauna that encompass a wider range of life modes relative to other observed fossil communities; from the stationary, reef-building, suspensionfeeding Atrypids, to the benthic, mobile detritus-feeding gastropods, to the nektonic, predatory orthocerids. The mollusk-rich fauna reflects deeper, more protected areas of the lagoon as evidenced by exceptional fossil preservation in basinal lagoon deposits. Lagoon exterior margins were characterized by tentaculitids and ostracods. The brachiopod-mollusk fauna is closely associated with the ostracod-rich lag deposits. The cyclic variations between these two faunas, along with similiarities in lithofacies and biofacies, suggests their depositional environments are very closely related, potentially representing respective ranges along the same ecological gradients. In one observed layer, the highly distinctive rhynchonellid brachiopod genus Stergerhynchus is present (Figure 6), marking the boundary between the underlying lagoon/ramp deposits and the overlying siliciclastic delta-front deposits.

\section{Shallow ramp shoreface communities}

Most common observed faunal assemblages consist of ostracods, articulate brachiopods, tabulate corals, sponges, gastropods, foraminifera, trilobites, palynomorphs, and bryozoans. 
These communities consist of more light-dependent reef-building organisms. Tabulate corals Favosites and Halysites, Trepostome Bryozoans, and unidentified sponges are the dominant reefbuilding organisms observed, reflecting a shallower-water setting in the shallow-subtidal to inner ramp shoal zone. Although still present in shoal deposits, crinoid abundancy is lower relative to deeper water deposits. Tentaculitids occur abundantly in the stratigraphically lowest sections of inner ramp-shoal successions, and gradually decreasing in abundancy going up-section. This faunal transition likely reflects changes in ocean anoxia, where occurrences of tentaculitids are generally associated with low oxygen levels. Ostracod death assemblages appear on the surface of laminated peloidal grainstone beds, highly abundant and commonly comprise over $90 \%$ of the observed fauna. Where mass accumulations of tiny ostracods are observed, these forms comprise over $90 \%$ of the observed fauna, sometimes associated with gastropods, Rhynchonellid brachiopods, and tentaculitids. Gastropods, the brachiopod Dalmanella, crinoid fragments, and tentaculitids are commonly observed in association with ostracods in some grainstone horizons. Peloidal concentration and grain size also increases in these beds, containing fine grained quartz sands. Tabulate corals are observed in the brown, silty micritic matrix of bed bases. In one observed bed, the ostracod-rich beds include valves of the exceptionally large $(\sim 1 \mathrm{~cm})$ ostracod specimen, Leperditia alta.

\section{Tidal flat communities}

Faunal communities residing in tidal flats and channels exhibit the least faunal diversity within the observed depositional systems. These communities are characterized by high abundance but low diversity of taxa. Most of the taxa present here are known from brackish water conditions. Observed taxa predominantly include the bivalve Leiopteria and ostracods, although rare occurrences of brachiopods, eurypterids, and gastropods are known. Traces of the inarticulate brachiopod Lingula are rare within beds of brown mudstone and bases of massive microcrystalline carbonate. Given the low abundance and diversity within these fossil communities, the ichnogenera present in different beds has been especially helpful in assessing the ecology of this depositional setting. This fauna seems to be dominated by infaunal burrowers and benthic-dwelling mobile organisms. 


\section{CONCLUSIONS}

\section{Depositional history}

Stratigraphic analysis of the Bellwood locality unravels the evolution of a stormdominated carbonate ramp system. The sequence stratigraphy represents a general shallowingupward transition from carbonate-dominated ramp environments to transitional siliciclasticcarbonate tidal environments. Frequency of storm events during the late Silurian played an integral role in maintaining carbonate ramp buildup. This interpretation of storm-driven depositional processes is consistent with those of other studies conducted on related middle Silurian basin deposits, including the Mifflintown Formation (Cotter, 1990). Tidal processes apparently influenced depositional processes along the low-gradient ramp during periods of fair weather.

The middle ramp zone was subject to intervals of high-energy and sediment reworking during storm events, where storm waves penetrated below fair-weather wave base. The ratio of carbonate and siliciclastic mudstone to wackestone-packstone increases toward distal middle ramp settings, represented by successions of green siliciclastic mudstones with thin interbeds of bioclastic wackestone-packstones. Shallower ramp deposits reflect deposition in upper-plane bed regimes, corresponding to the shoreface. As a result, planar laminae and bedding are the prevalent sedimentary structures observed here. The transition to predominantly siliciclasticdominated lithologies observed in the stratigraphically youngest deposits, represented by intraclastic conglomerate beds, reflects the progradation of a coastal delta system resulting from either a decrease in relative sea level or an increase in sedimentation relative to erosion. As the delta extended basinward, it developed a network of subaqueous channels which supplied an influx of fine-grained siliciclastic material into the subtidal zone. Storm-generated processes are a dominant mechanism of deposition in this carbonate-siliciclastic transitional system. Turbidity currents may have played a role in controlling the stability and stratigraphic architecture of the delta slope, evidenced by intraclastic conglomerates. Storm waves ripped up and reworked the sediment, which may have led to instability and subsequent mass wasting along the pro-delta slope, thus producing intraclastic conglomerate channel-fill beds (Tirsgaard, 1992; Myrow et al, 2004). Some conglomerate beds may represent delta fan deposits, which would have formed near breaks in slope gradient as a function of sudden change in regime flow, when turbulent bottomflows hit deeper water and suddenly lost energy, consequently dumping their sediment loads. Beds in this transitional siliciclastic-carbonate depositional setting either form tempestites or 
turbidites, which are often hard to decipher given the incompleteness of stratigraphic successions due to erosional processes. Previous literature has interpreted the Mifflintown and Bloomsburg formations as representing epeiric ramp and delta plain depositional environments, respectively (Hoskins, 1962; Cotter, 1990; Driese et al, 1992). Stratigraphic analysis of the Bellwood outcrop supports these depositional environmental interpretations.

\section{Paleoecological Summary}

The paleoecology appears to remain relatively stable through time, largely dominated by stationary epifaunal suspension feeders. Shifts in paleoecology are related to changes in substrate consistency, sediment supply, and salinity, all variables that seem to be a function of water depth and stratigraphic architecture. Faunal composition in reef-building communities varies between distal and proximal ramp settings. Such taxonomic shifts may suggest faunal replacement or biotic competition was a driver, however, more quantitative ecological data would be needed to answer such questions. Changes in depositional setting, specifically relating to stratigraphic architecture, energy levels, water depth, and substrate consistency, were a major driver of taxonomic changes in faunal communities, as illustrated by the replacement of taxa by similarly functioning taxa. Articulate brachiopods were the most common fossil fauna observed across depositional environments with normal marine salinities. The abundance of articulate brachiopod specimens relative to other faunal groups is likely an artifact of high preservation potential due to their hard, mineralized valves. At the population level, brachiopod groups tend to vary based on substrate consistency, and can be used as relative depth indicators. In deeper, low-energy environments with muddy substrates, the thin-shelled strophomenids dominate faunal assemblages. In shallower, higher-energy environments, the more robust rhynchonellids dominate. During the late Ordovician, cephalopods began to inhabit more pelagic realms opposed to benthic (Kroger et al, 2009). The presence of swimming orthocerid in basinal lagoon deposits suggests pelagic cephalopods were still trending in the late Silurian and possibly expanded their niches even more.

Overall, gastropods and ostracods are the most widespread organisms across different faunal communities and environments, demonstrating their resilience to change. Occurrence of gastropods and ostracods occur in lagoons, reef shoals, and tidal-deltaic settings. Articulate brachiopods tend to dominate in realms below fair-weather wave base, for the most part occurring in middle and outer ramp deposits. There are some articulate brachiopods found 
associated with reef communities, particularly Dalmanella and some rhynchonellids. Articulate brachiopods also potentially occur within fine-grained deltaic deposits; however, the poorpreservation makes it difficult to determine. Shallower-water settings are dominated by ostracods.

The Eurypterid tergite fossil finding within tidal deposits has significant implications for better understanding late Silurian shallow marine paleoecology. Eurypterid fossils are relatively rare in the geologic record but have been observed in various marine and brackish environments (Vrazo et al, 2014). Eurypterid fossils are better known from the northern Appalachian basin (Indiana, New York, Ontario) compared to central and southern portions of the Appalachian basin (Pennsylvania, Maryland, and West Virginia) (Vrazo et al, 2014). The finding of these rare fossils in this region suggests depositional environments are similar between similar-aged deposits of both north and southern basins. This suggests the lack of observed fossil Eurypterids in the south may be due to the under-sampling of paleontology, rather than major differences in depositional environment that would affect eurypterid habitats.

Spatial Trends in Mifflintown/Bloomsburg Paleoecology

The Bellwood locality represents a more distal location from the Bloomsburg Formation type section in Bloomsburg, PA to the central basin. Here, the rocks exhibit higher concentration of carbonate lithologies, and greater diversity and abundance of shallow marine fossil fauna relative to other described Bloomsburg localities. The lithologies, paleoecologies, and paleocommunity compositions of Bellwood are comparable to the westernmost Bloomsburg localities that have been described by Hoskins (1961), namely the Hollidaysburg and Mt. Union localities. Towards the east, the Bloomsburg localities become dominated by siliciclastic lithologies as a function of proximity to the terrigenous source area, which would have been the Taconic mountain range during the middle to upper Silurian (Cotter, 1990). At localities near the type section, the Bloomsburg Formation is exposed as a discrete unit separate from the underlying Mifflintown Formation In westward localities, the Mifflintown and Bloomsburg Formations become undifferentiated and produce an interfingering stratigraphic pattern, reflecting cyclic changes in water depth associated with frequently fluctuating sea level. Of all observed Mifflintown/Bloomsburg outcrops, the Bellwood locality yields the highest apparent taxonomic richness, including fossil fauna that are either rare or absent at other localities (Figure 22). The orthocerid nautiloid specimens observed in fossiliferous mudstone-wackestone beds at 
the Bellwood locality have not been documented elsewhere in the Bloomsburg and Mifflintown Formations. Eurypterid fragments are very rare and have otherwise only been observed in rare occurrences at the Mt. Union locality (Hoskins, 1961), but are also known from the overlying Tonoloway Fm. (Vrazo, 2014). Occurrence of Cornulites in the undivided Mifflintown/Bloomsburg Formations has been observed very rarely in the marine strata (Hoskins, 1961).

\section{Future Work}

This study provides the first formal stratigraphic and paleontological assessment of the undivided Mifflintown/Bloomsburg Formations exposed in Bellwood, PA, thus can be used as a framework for further biodiversity studies of this area. Although the available data was sufficient to illustrate general trends in depositional environment and paleoecology, further analysis of the data is needed to evaluate shifts in paleoecology and taxonomic composition of communities at a high resolution. Specifically, fossil abundance and diversity data are needed to assess temporal shifts in biodiversity patterns at individual localities, as well as to compare biodiversity trends spatially among localities. The dearth of paleontological-based studies on the Mifflintown/Bloomsburg Formations hinders the ability to compare paleoecological trends in a spatial context. Paleoecological trends that appear to shift spatially could potentially be owed to differences in sampling resolution and intensity among studies. Another concern is how fossil data is measured, which tends to vary by study. For example, taxa rated with an occurrence of 'very rare' is subjective based on the study and does not offer a means of quantitative comparison with other studies. Despite the lack of paleontological data and discrepancies in paleontological measurements, this study has provided paleoenvironmental and paleontological data for future researchers to assess general paleoecological trends of the Bellwood locality. 


\section{REFERENCES}

Anadon, P., Gliozzi, E., Mazzini, I., 2002, Paleoenvironmental Reconstruction of Marginal Marine Environments From Combined Paleoecological and Geochemical Analyses on Ostracods: The Ostracoda: Applications in Quaternary Research, Geophysical Monograph v. 131, p. 227-247.

Anya, H.V., and Trop, J.M., 2019, Sedimentology and carbon isotope stratigraphy of SilurianDevonian boundary interval strata, Appalachian basin (Pennsylvania, USA): Palaios, v. 34, no. 9, p. $405-423$.

Baniak, G.M., Amskold, L., Konhauser, K.O., Muehlenbachs, K., Pemberton, S.G., Gingras, M.K., 2014, Sabkha and Burrow-Mediated Dolomitization in the Mississippian Debolt Formation, Northwestern Alberta, Canada; Ichnos, v. 21, p. 158-174. Research Gate.

Burchette, T.P., and Wright, V.P., 1992, Carbonate ramp depositional systems: Sedimentary Geology, v. 79, p. 3-57.

Cotter, Edward, 1990, Storm Effects on Siliciclastic and Carbonate Shelf Sediments in the Medial Silurian Succession of Pennsylvania: Sedimentary Geology, v. 69, p. 245-258.

Donovan (ed.)., 1993, "Bottjer and Droser, The history of Phanerozoic bioturbation”, The palaeobiology of trace fossils.

Driese, S.G, Mora, C.I, Cotter, E., Foreman, J.L, 1992, Paleopedology and Stable Isotope Chemistry of Late Silurian Vertic Paleosols, Bloomsburg Formation, Central Pennsylvania: Journal of Sedimentary Petrology, v. 62, no. 5, p. 825-841.

Dunham, R. J., 1962, Classification of carbonate rocks according to depositional texture. In: Ham, W. E. (ed.), Classification of carbonate rocks: American Association of Petroleum Geologists Memoir, p. 108-121.

Embry, AF, and Klovan, JE, 1971, A Late Devonian reef tract on Northeastern Banks Island, NWT: Canadian Petroleum Geology Bulletin, v. 19, p. 730-781.

Ettensohn, F.R., 2008, The Appalachian Foreland Basin in Eastern United States. In: K.J. Hsu, editor: Sedimentary Basins of the World, Vol 5, The Sedimentary Basins of the United States and Canada, Andrew D. Miall. The Netherlands: Elsevier. p. 105-179.

Folk, R.L., 1962, Spectral subdivision of limestone types, in W.E Ham (ed.), Classification of carbonate rocks: Am. Assoc. Petroleum Geologists Mem. 1. Table 1, p.70.

Fursich, F.T., and Hurst, J.M, 1974, Environmental Factors Determining The Distribution of Brachiopods: Palaeontology, v. 17, part 4, p. 879-900. 
Garlock, T.L, and Isaacson, P.E, 1977, An Occurrence of a Cruziana Population in the Moyer Ridge Member of the Bloomsburg Formation (Late Silurian)-Synder County, Pennsylvania: Journal of Paleontology, v. 51, no. 2, p. 282-287.

Hajlaz, B., 1974, TENTACULITES OF THE UPPER SILURIAN AND LOWER DEVONIAN OF POLAND: Palaeontologica Polonica, Vol. XIX. no. 4.

Holland, S.M, 2012, Sea level change and the area of shallow-marine habitat: implications for marine biodiversity: Paleobiology, v. 38, no. 2., p. 205-217.

Holland, S.M., and Patzkowsky, M.E., 2007, Gradient Ecology of Biotic Invasion: Biofacies of the Type Cincinnatian Series (Upper Ordovician), Cincinnati, Ohio Region, USA: Palaios, v. 22., p. 392-407.

Hoskins, Donald M., 1961, Stratigraphy and Paleontology of the Bloomsburg Formation of Pennsylvania and Adjacent States: Pennsylvania Geological Survey, s. 4, Bulletin G 36.

Johnson, M.E., 2006, Relationship of Silurian sea-level fluctuations to oceanic episodes and events: GFF, Vol. 128 (Pt. 2, June), pp. 115-121.

Johnson, N.G., 1985, Early Silurian Palynomorphs from the Tuscarora Formation in Central Pennsylvania and Their Paleobotanical and Geological Significance: Review of Palaeobotany and Palynology, vol. 45, p. 307-360.

Kreisa, R, 1981, Storm-generated structures in subtidal marine facies with examples from the middle and upper Ordovician of southwestern Virginia: Journal of Sedimentary Petrology, v. 51, no. 3, p. 0823-0848.

Kroger, B., Servais, T., and Zhang, Y., 2009, The origin and initial rise of pelagic cephalopods in the Ordovician: PLoS One, v. 4, no. 9.

Morris, R.W., and Rollins, H.B., 1971, The Distribution and Paleoecological Interpretation of Cornulites in the Waynesville Formation (Upper Ordovician) of Southwestern Ohio: Ohio Journal of Science, v. 71, no. 3.

Rasmussen, C.M., Kröger, B., Nielsen, M.L., Colmenar, J., 2019, Cascading trend of Early Paleozoic marine radiations paused by Late Ordovician extinctions: PNAS: Earth, Atmospheric, and Planetary Sciences.

Sclafani, J. A., Congreve, C.R., Krug, A.Z., and Patzkowsky, M.E., 2018, Effects of mass extinction and recovery dynamics on long-term evolutionary trends: a morphological study of Strophomenida (Brachiopoda) across the Late Ordovician mass extinction; Paleobiology, v. 44, no. 4, p. 603-619. 
Shin, E.A., 1983, Chapter 4: Tidal flat, in Bebout, D.G., Moore, C.H., and Scholle, P.A., ed., Carbonate Depositional Environments: Tulsa, Oklahoma, The American Association of Petroleum Geologists, v. p. 171-210.

Swett, K., and Smit, D.E., 1972, Paleogeography and Depositional Environments of the Cambro-Ordovician Shallow-Marine Facies of the North Atlantic: Geological Society of America Bulletin, v. 83, p. 3223-3248.

Tackett, L.S, and Bottjer, D.J., 2016, Paleoecological Succession of Norian (Late Triassic) Benthic Fauna in Eastern Panthalassa (Luning and Gabbs Formations, West-Central Nevada): Palaios, v. 31, p. 190-202.

Tirsgaard, H., 1996, Cyclic Sedimentation of Carbonate and Siliciclastic Deposits on a Late Precambrian Ramp: The Elisabeth Bjerg Formation (Eleonore Bay Supergroup), East Greenland: Journal of Sedimentary Research, vol. 66., No. 4, p. 699-712.

United States Naval Academy, The U.S Navy:

https://www.usna.edu/Users/oceano/pguth/md_help/geology_course/apparent_dip_and_thickness .htm

Vrazo, M.B., Trop, J.M., Brett, C.E., 2014, A New Eurypterid Lagerstatte from the Upper Silurian of Pennsylvania: PALAIOS, v. 29, 431-448. 


\section{FIGURES}



Figure 1: Locus map for the Bellwood locality, located in Blair County, Central Pennsylvania. Red rectangle on state map corresponds to area represented by local Bellwood area map (yellow map). Star represents the Bellwood locality, pictured in the Google Earth image. 


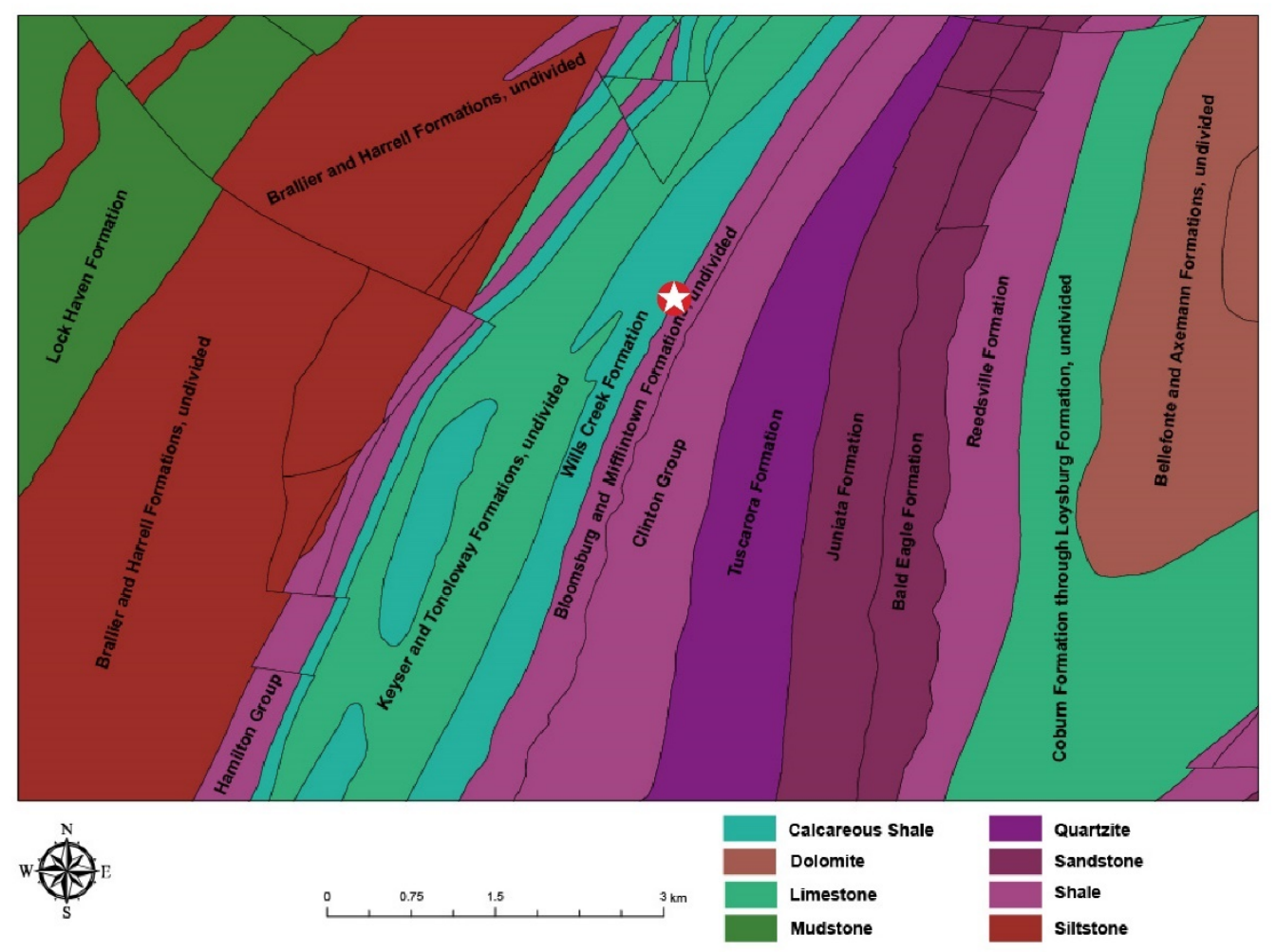

Figure 2: Lithologic map of central PA area, showing a trend from siliciclastic to carbonate rock on the western limb of the Nittany Anticline, central PA. Then, Devonian formations represent siliciclastic rock. 


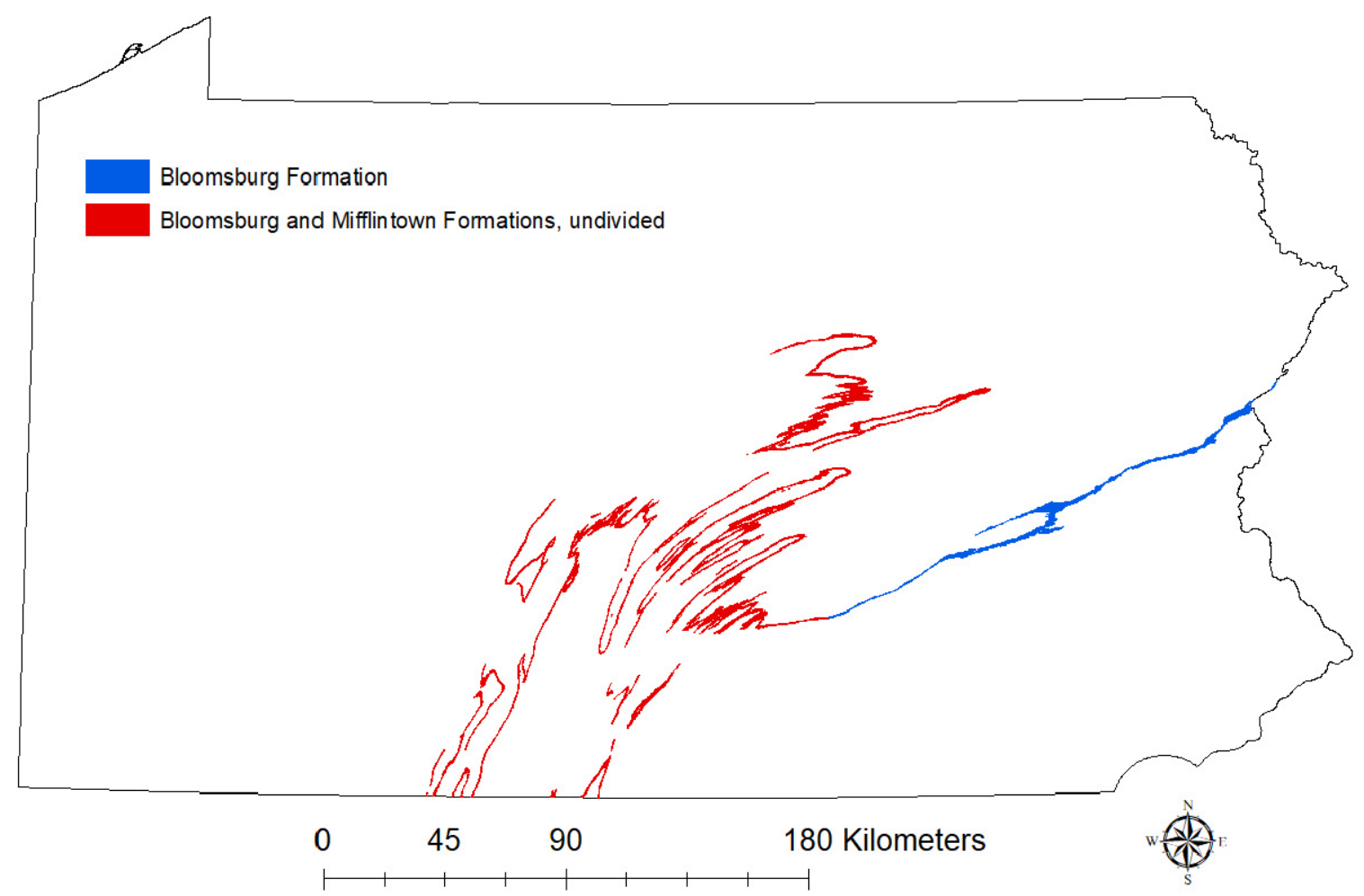

Figure 3: Extent of the undifferentiated Mifflintown-Bloomsburg Formation outcrop exposures within Pennsylvania. Areas in blue denote the Bloomsburg Formation without association with the Mifflintown, reflecting siliciclastic-fluvial system deposits rather than the more carbonaterich deposits towards the west (Hoskins, 1961). 


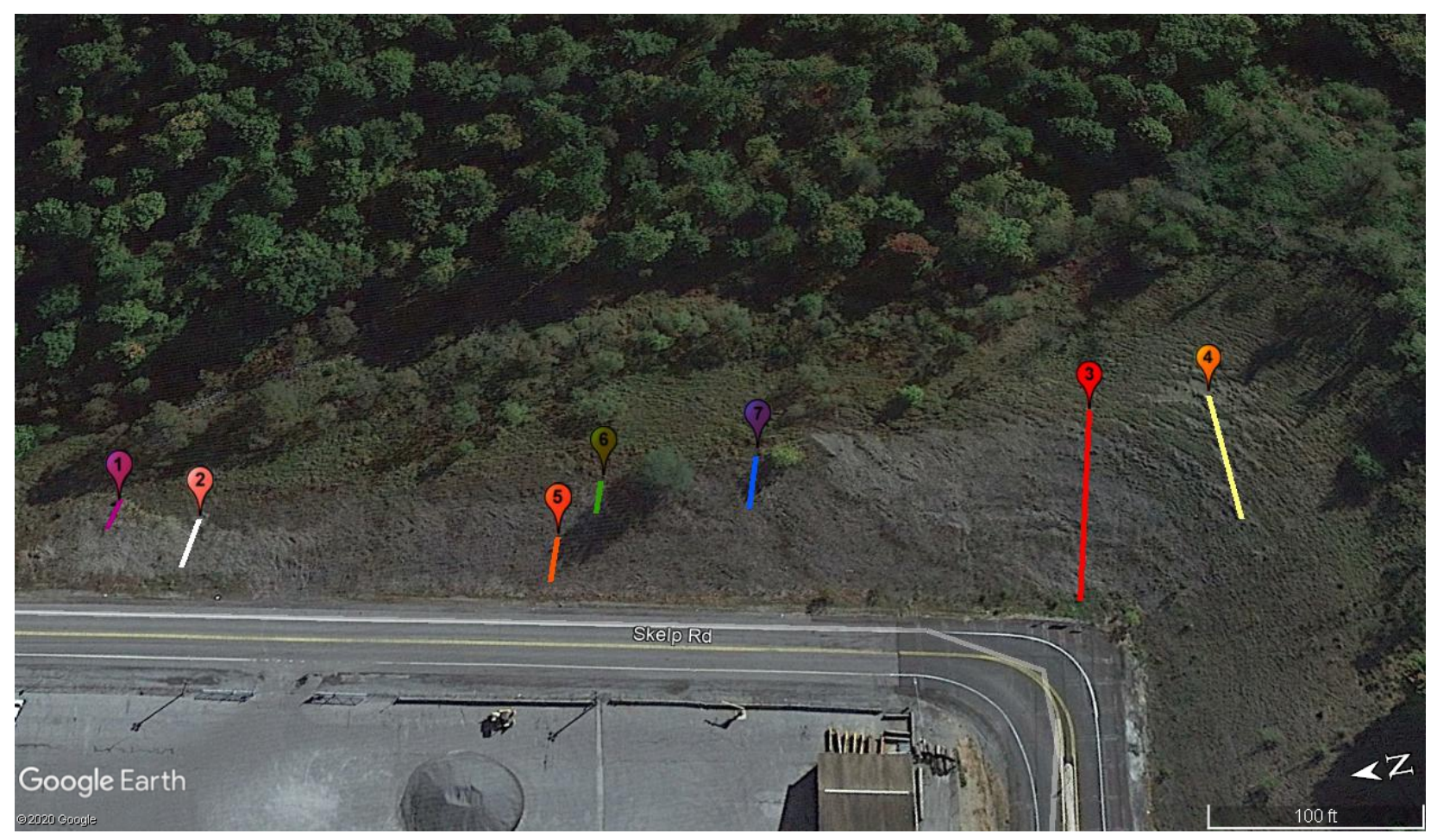

Figure 4: Map showing location of transects where stratigraphic profiles were measured and described. (Note that stratigraphic profiles for transects 1 and 2 were not constructed due to lack of bedding measurements.) 


\section{Lithologic Key}

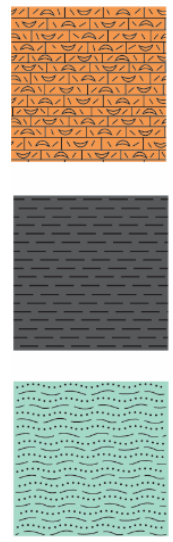

L1: Bioclastic wackestone-packstone



L6: Recrystallized bioclastic packstone

L7 - intraclastic and detrital conglomerates:

L2: Siliciclastic mudstone

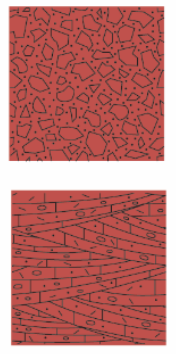

Intraclast-rich beds

L3: Mottled nodular-bedded packstone

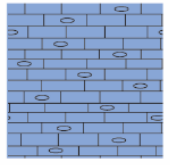

HCS detrital carbonate

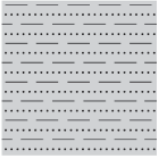

L4: Fossiliferous mudstone-wackestone with siliciclastic interbeds

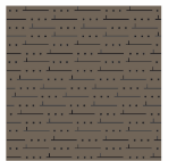

L8 - Massive microcrystalline carbonate

L5: Laminated peloidal grainstone with brown calcareous mudstone

L9: Brown calcareous mudstone

Figure 5: Lithologic symbol key for the illustrated stratigraphic profiles (figures 6-10). 


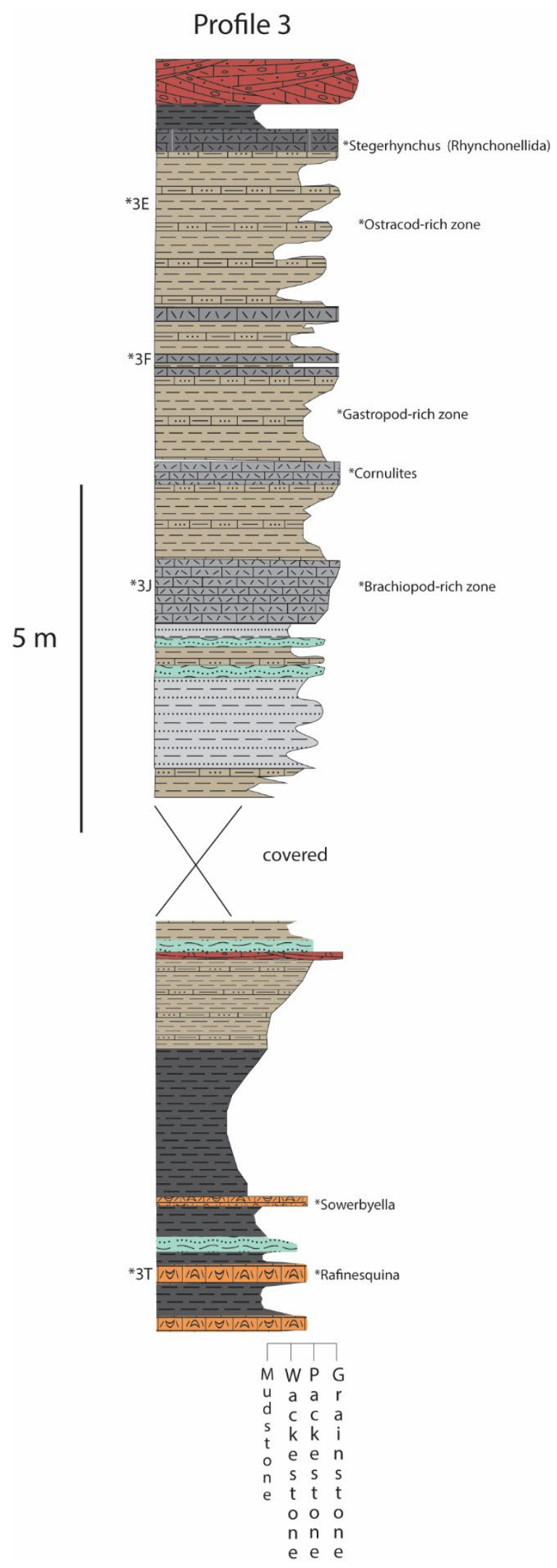

Figure 6: Stratigraphic profile 3 largely reflects the transition from shallow subtidal middle ramp environments to shallower lagoonal environments. 




Figure 7: Profile 4 represents stratigraphically oldest deposits observed, and correlates well with the bottom of profile 3. This section largely represents deposition in middle ramp settings, with $L 1$ reflecting slightly deeper or more distal middle ramp zones, while beds of L3 reflect slightly shallower or more proximal middle ramp zones, based on sedimentary structures, lithology, and faunal composition. 


\section{Profile 5}

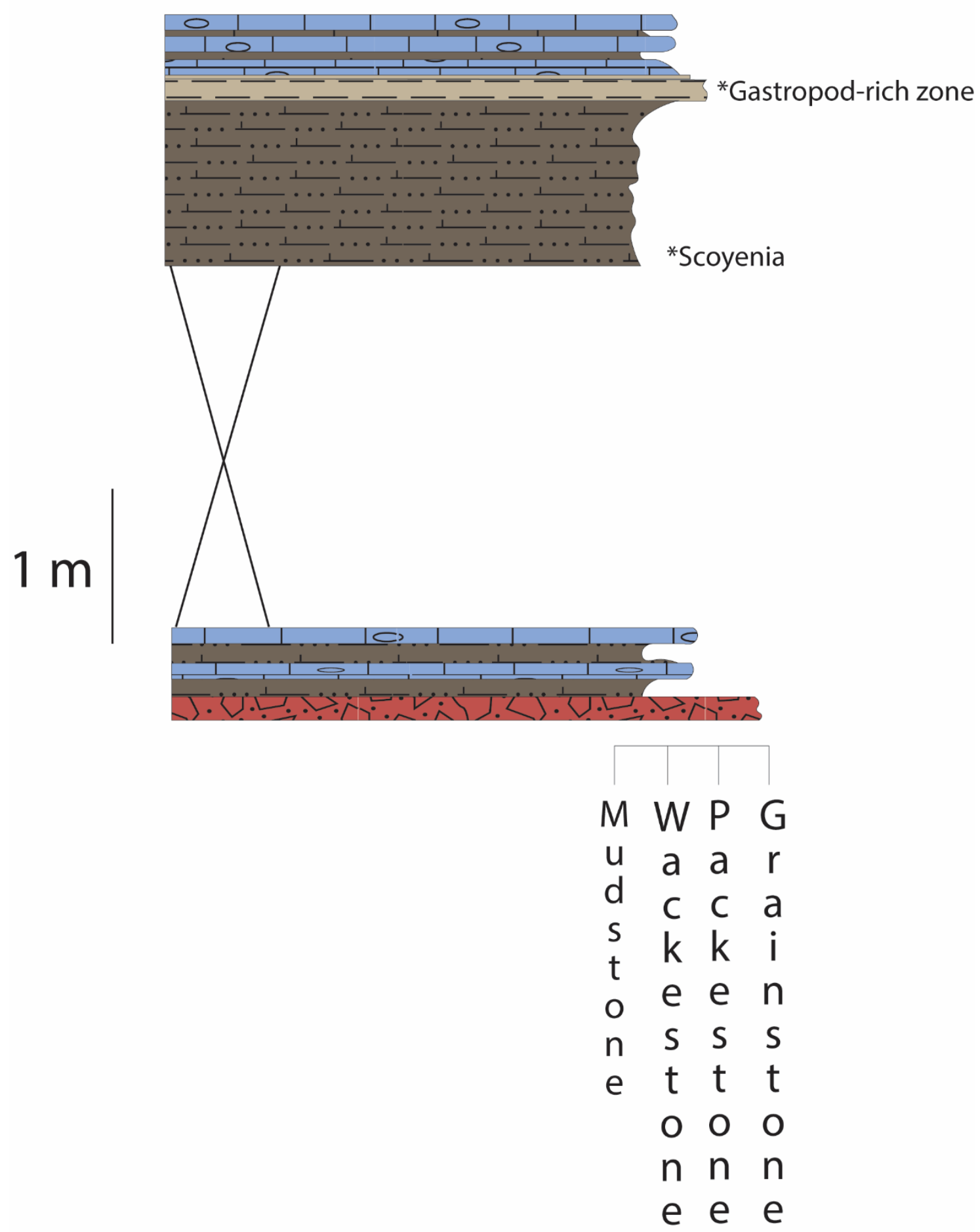

Figure 8: Profile 5 represents the stratigraphically youngest units and is dominated by massivebedded microcrystalline carbonate (L8) interbedded with mixed calcareous and non-calcareous mudstones (L9). 


\section{Profile 6}


Figure 9: Profile 6 includes sequences of massive microcrystalline carbonates (L8) interbedded with brown calcareous and non-calcareous mudstones (L9). This profile largely reflects deposition in the tidal zone, based on prominence of algal laminae and veins of recrystallized calcite. Brown mudstones represent tidal flat environments, evidenced by low fossil diversity, mud to silt-sized grains, and variably calcareous to non-calcareous brown mudstones. 


\section{Profile 7}
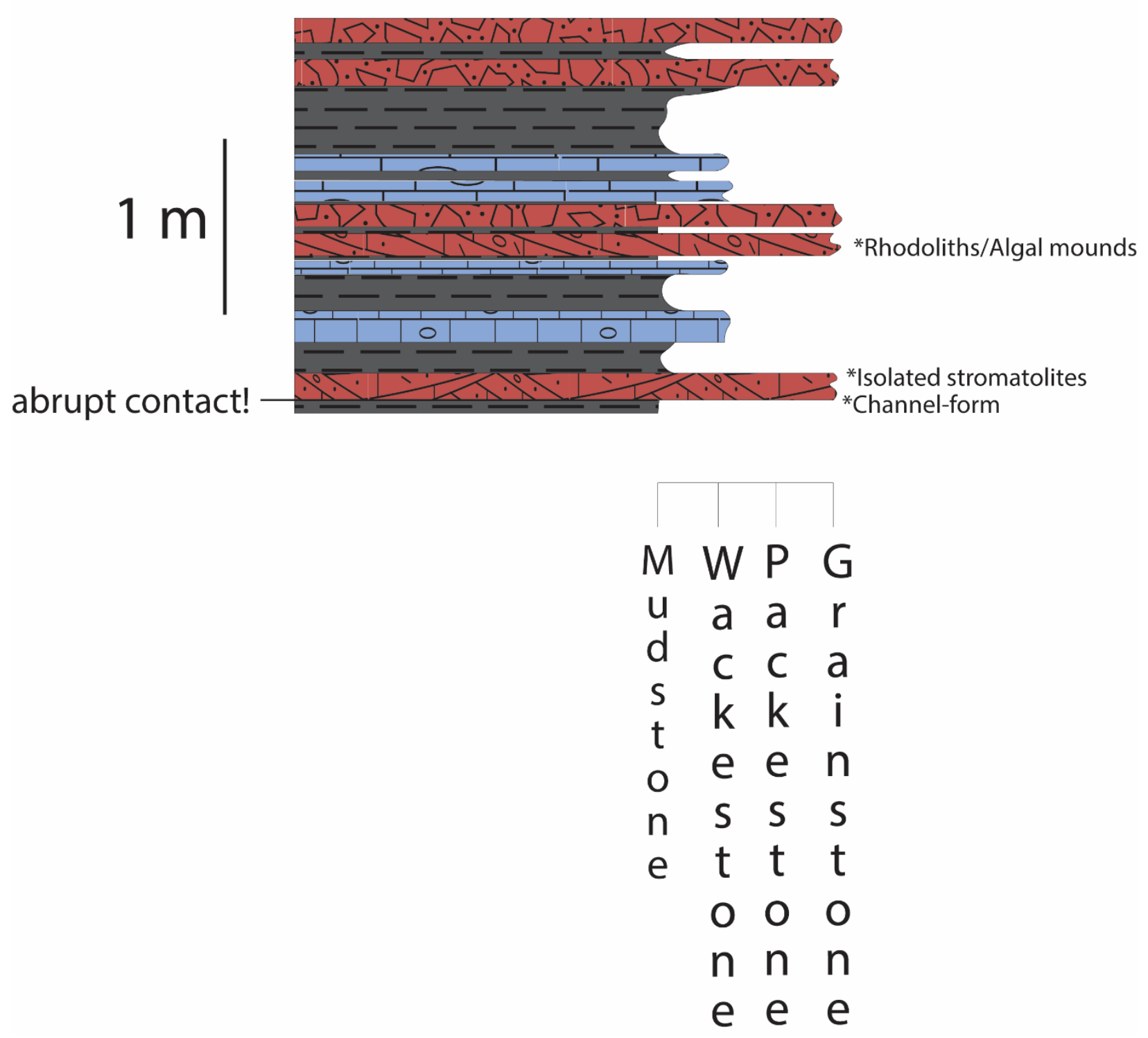

Figure 10: Profile 7, represented by associations of siliciclastic mudstones (L2), massive microcrystalline carbonates (L8), and intraclastic and detrital conglomerates (L7).Intraclastic conglomerate beds become more prevalent in this section relative to upper sections (profiles 5 and 6), occurrence of bedform features such as channel-fills, buckled bedding, scouring and gutter-fills increase. 


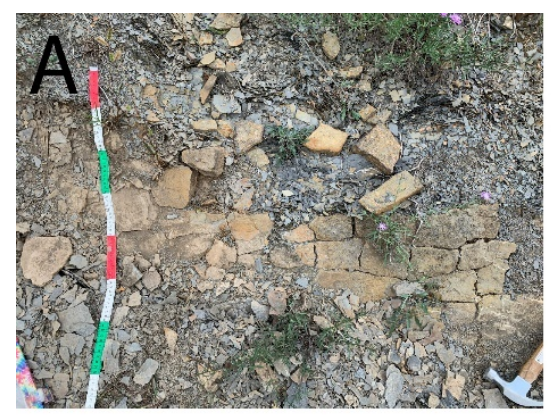

$40 \mathrm{~cm}$

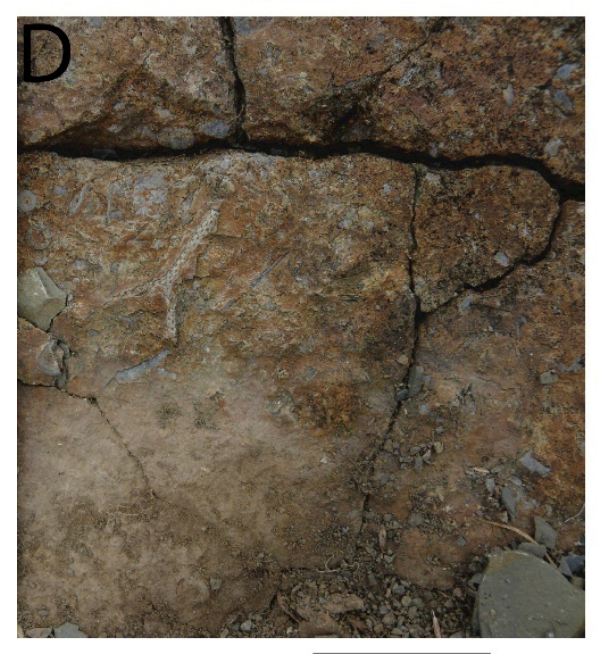

$5 \mathrm{~cm}$

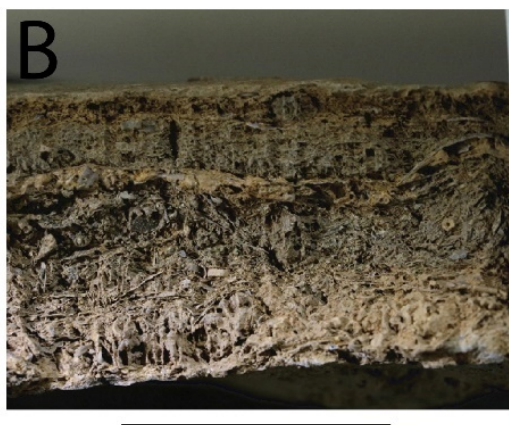

$3 \mathrm{~cm}$
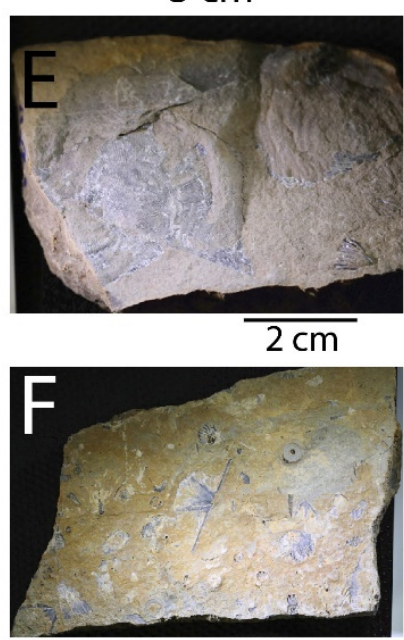

$\overline{2 \mathrm{~cm}}$

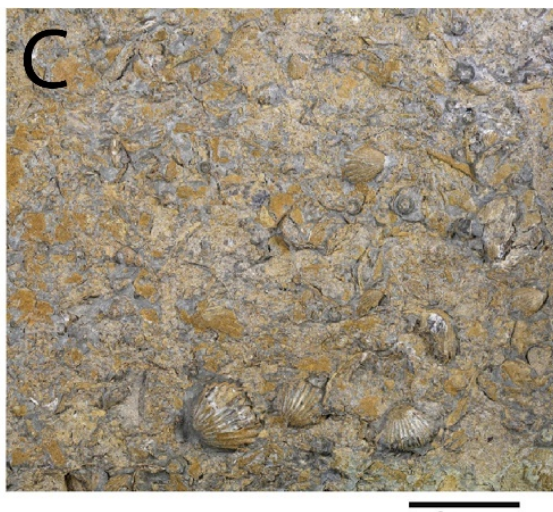

$1 \mathrm{~cm}$

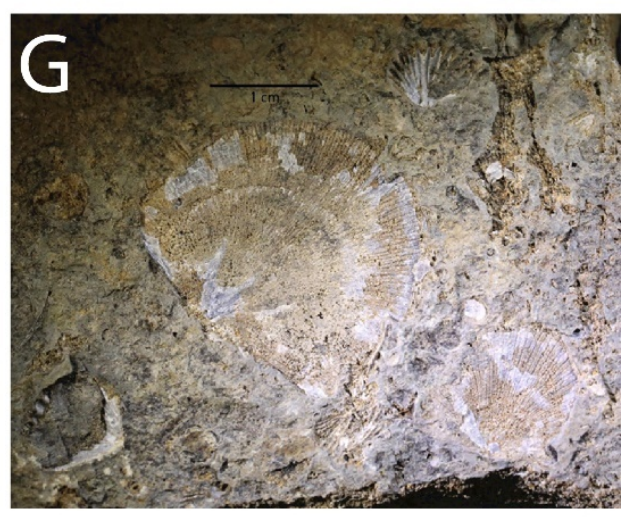

Figure 11: A. Typical outcrop of middle ramp storm deposits. B. Differential weathering on bioclastic wackestone-packstone beds. C. Eocelia and star-shaped crinoid ossicles in a typical fossiliferous assemblage within middle ramp storm beds. D. Trepostome Bryozoan observed in outcrop. E-F. The Strophomenid brachiopod Sowerbyella. G. The Strophomenid brachiopod, Rafinesquina (center view) with smaller Rhynchonellid brachiopods pictured to the sides. 

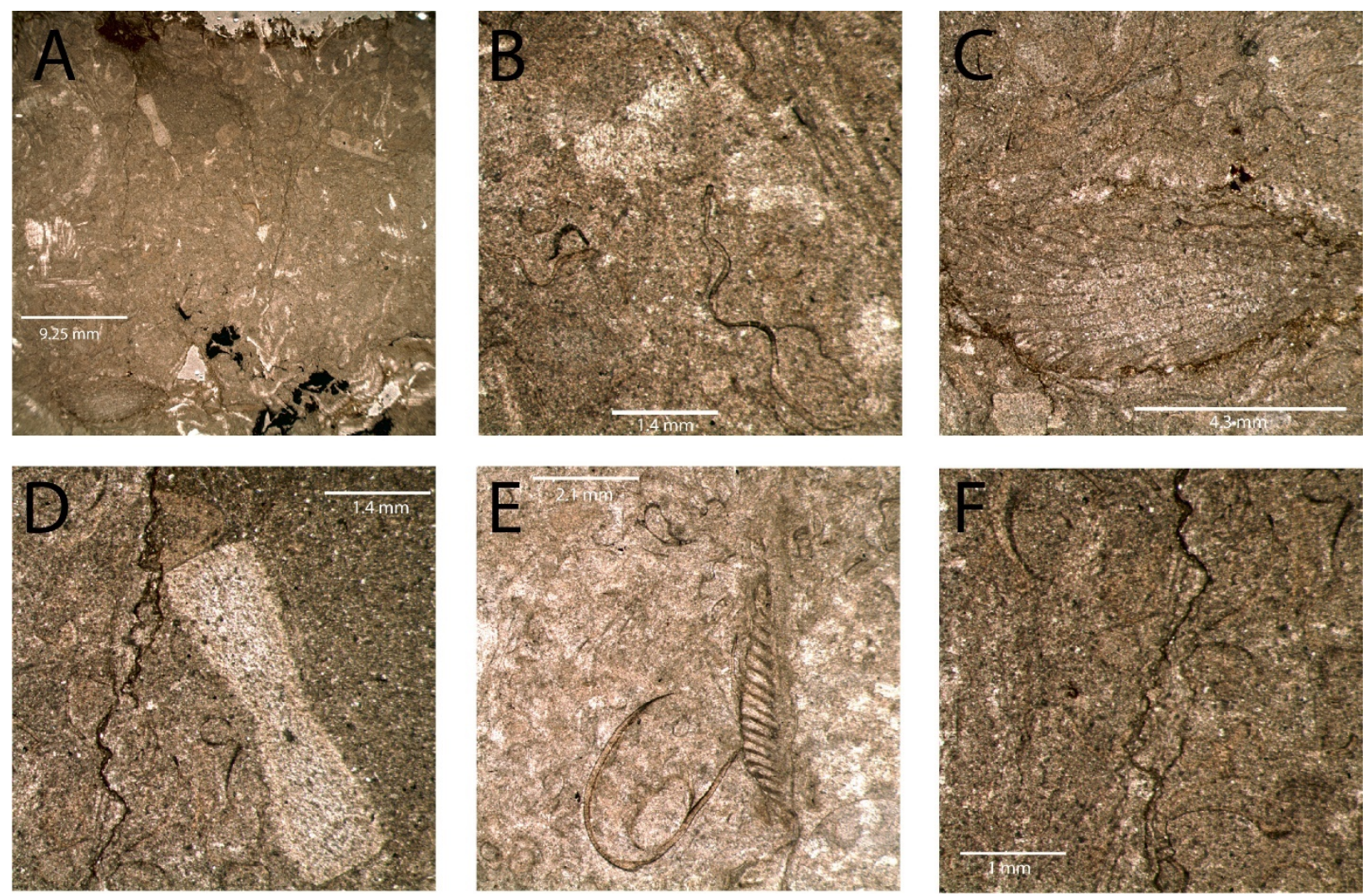

Figure 12: Petrography of facies 1 from stratigraphic profile 3, sample 3T; PPL. A. Broad view of wackestone-packstone with coarse skeletal debris B. Trilobite fragments (squiggly lines). $C$. Fenestrate Bryozoan. D. Unidentified echinoderm plates, including a large styolite and other compaction features to the left. E. Ostracod and brachiopod valves in a more cement-rich zone of the deposit F. Styolites. 

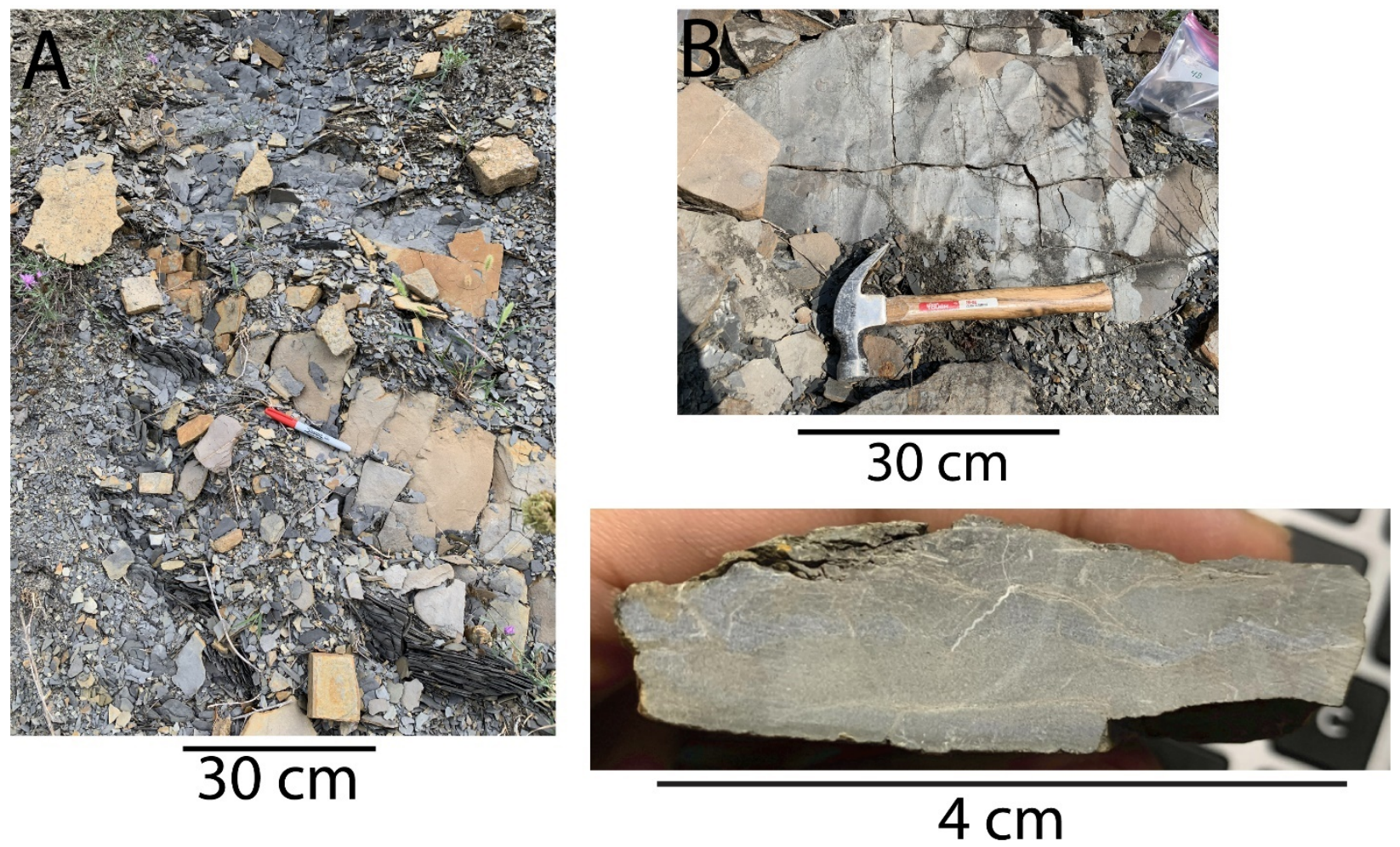

Figure 13: A. Association of fossiliferous mudstone-wackestone, mottled brown calcareous mudstones and packstones, and peloidal grainstones with fissile shale interbeds. B. Dolomitized base with symmetrical ripple marks. C. Wavy-laminated sandy carbonate and peloidal muds. 

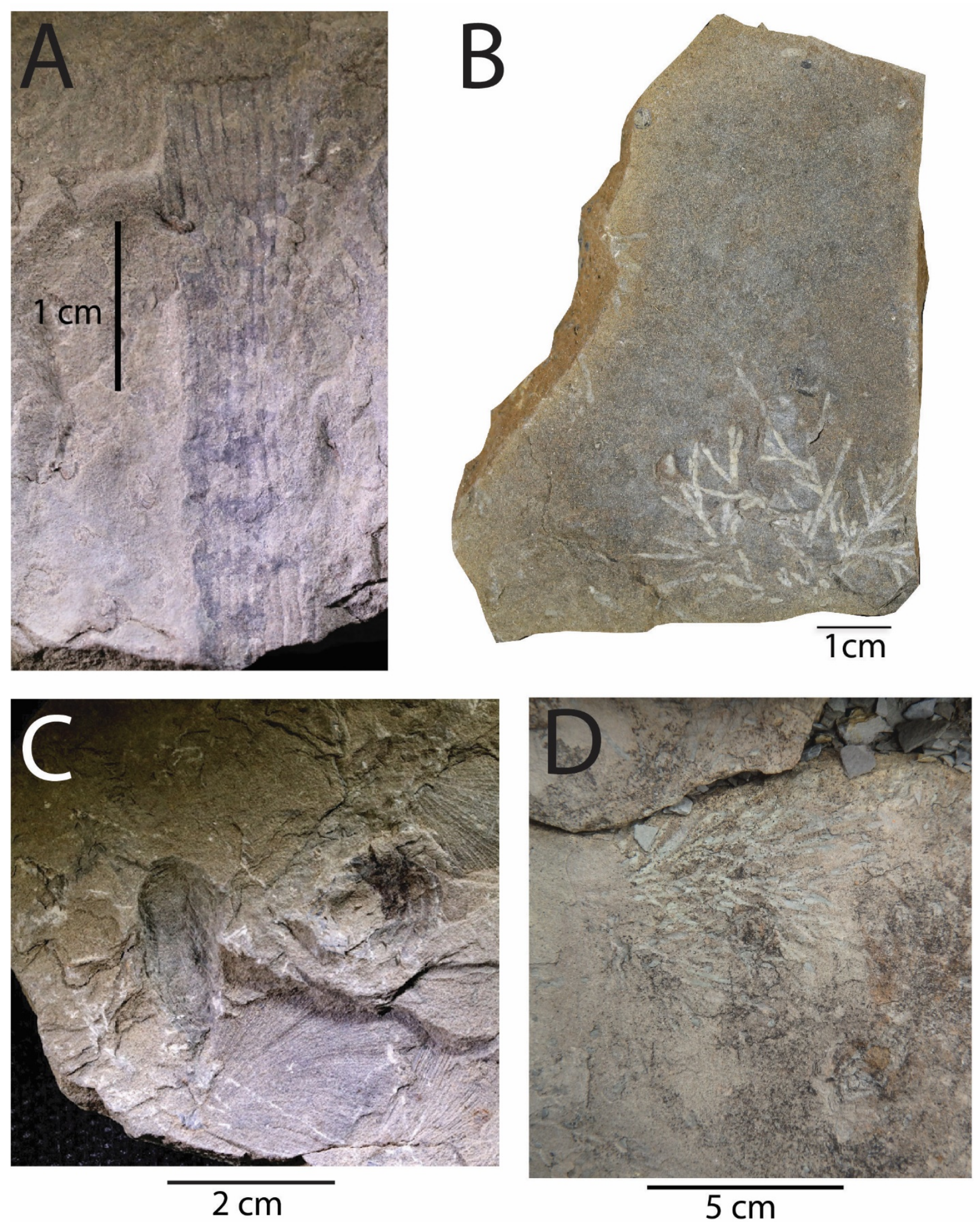

Figure 14: Biofacies associated with F3. A. Unidentified body fossil, potentially a tabulate coral. $B$. Chondrites feeding traces viewed on base of wavy-bedded packestone. C. Zoophycos trace fossil. D. Another view of Chondrites traces, observed in outcrop. 



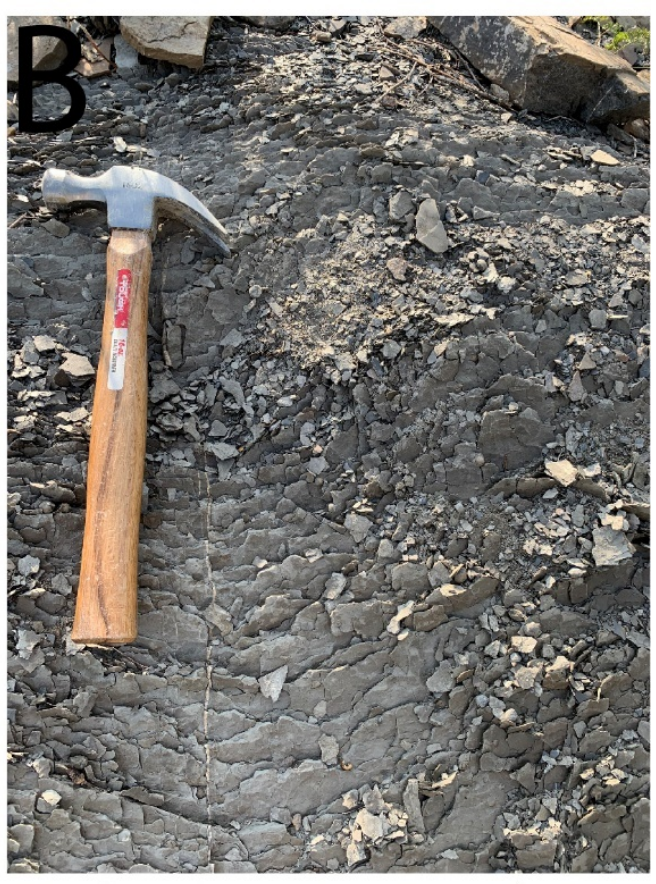

$25 \mathrm{~cm}$
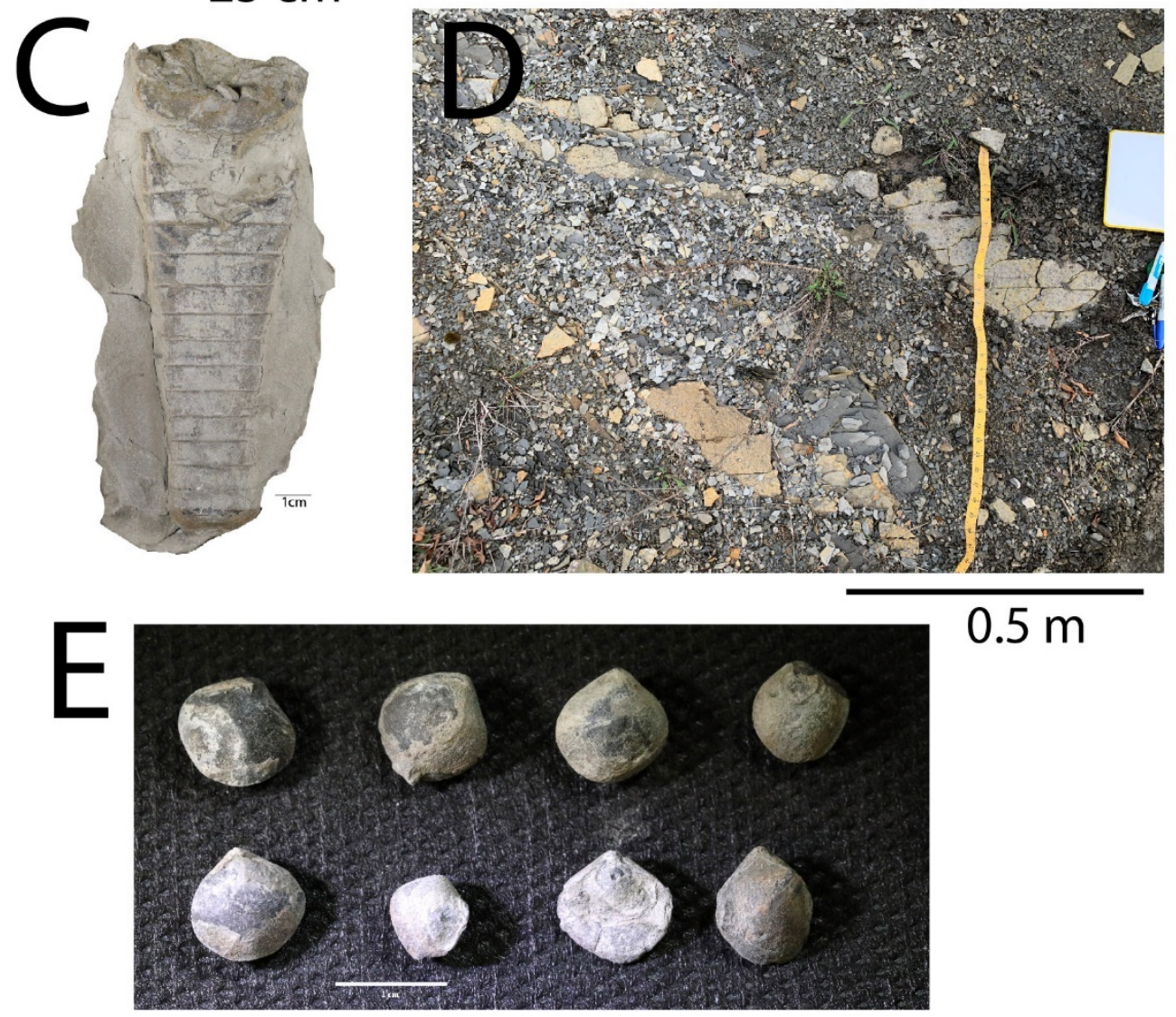

$0.5 \mathrm{~m}$ 
Figure 15: Fossiliferous mudstone-wackestone lithology (L4).

A-B. Typical outcrop, exhibiting highly friable and fissile mudstone layers.

C. Exceptionally preserved orthocerid nautiloid specimen.

D. Fossiliferous mudstone-wackestone in association with mottled nodular-bedded packstone

E. Atrypa brachiopods, the most abundant brachiopod form observed in this unit.

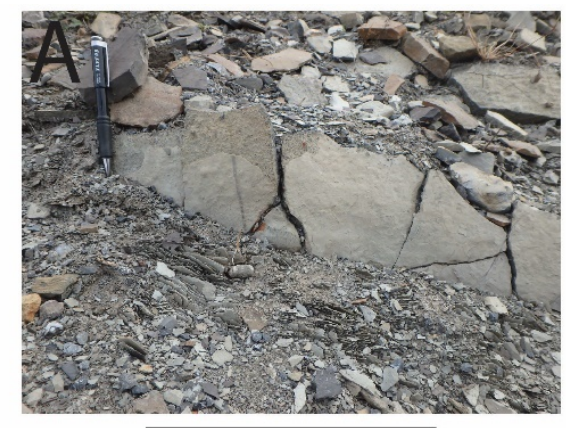

$26 \mathrm{~cm}$

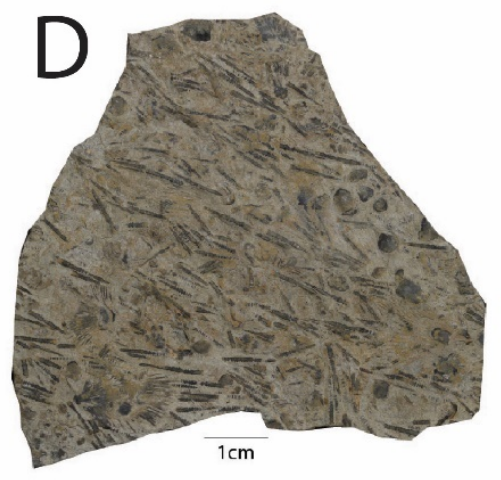

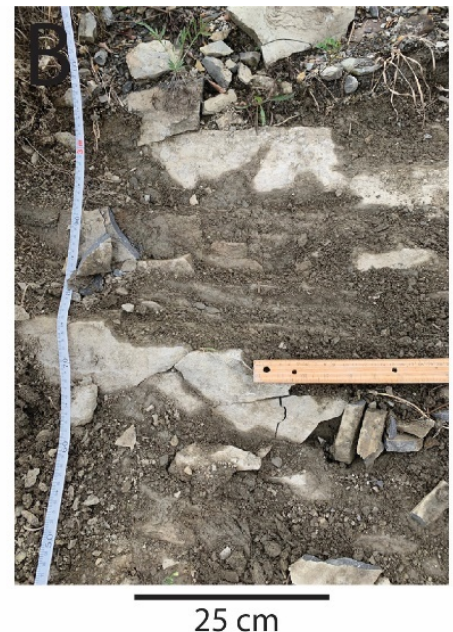

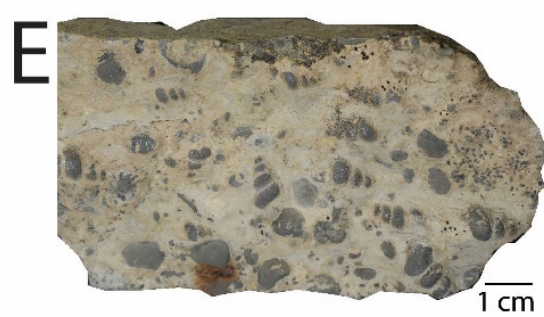



$1 \mathrm{~cm}$

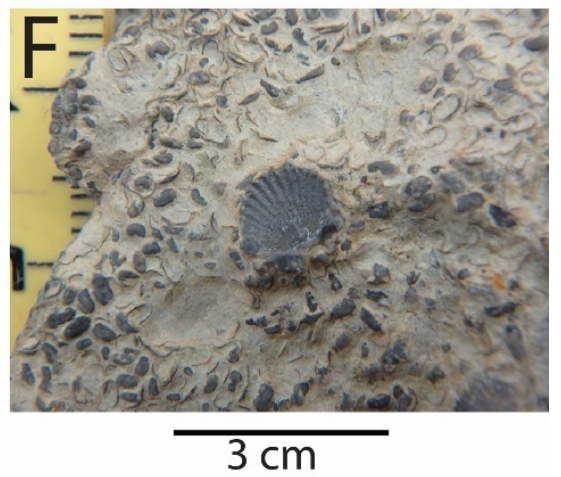

Figure 16:

A. Typical outcrop view of sandy peloidal packstone-grainstone beds interbedded with fissile brown mudstone (mudstone-rich successions).

B. Sandy peloidal packstone-grainstone forms amalgamated beds with recrystallized bioclastic packestone (L6), with interbeds of fissile brown mudstone in packstone-dominated successions. C. Hand sample view of peloidal sandstone bedding surfaces, showing mass accumulation of ostracods.

D. Skeletal grainstone bed yielding rare bedding surface with abundance of Tentaculitid specimens, viewed in association with Atrypa and Hebertella brachiopods.

E. Gastropod-rich layer.

F. The Orthid brachiopod, Damanella 

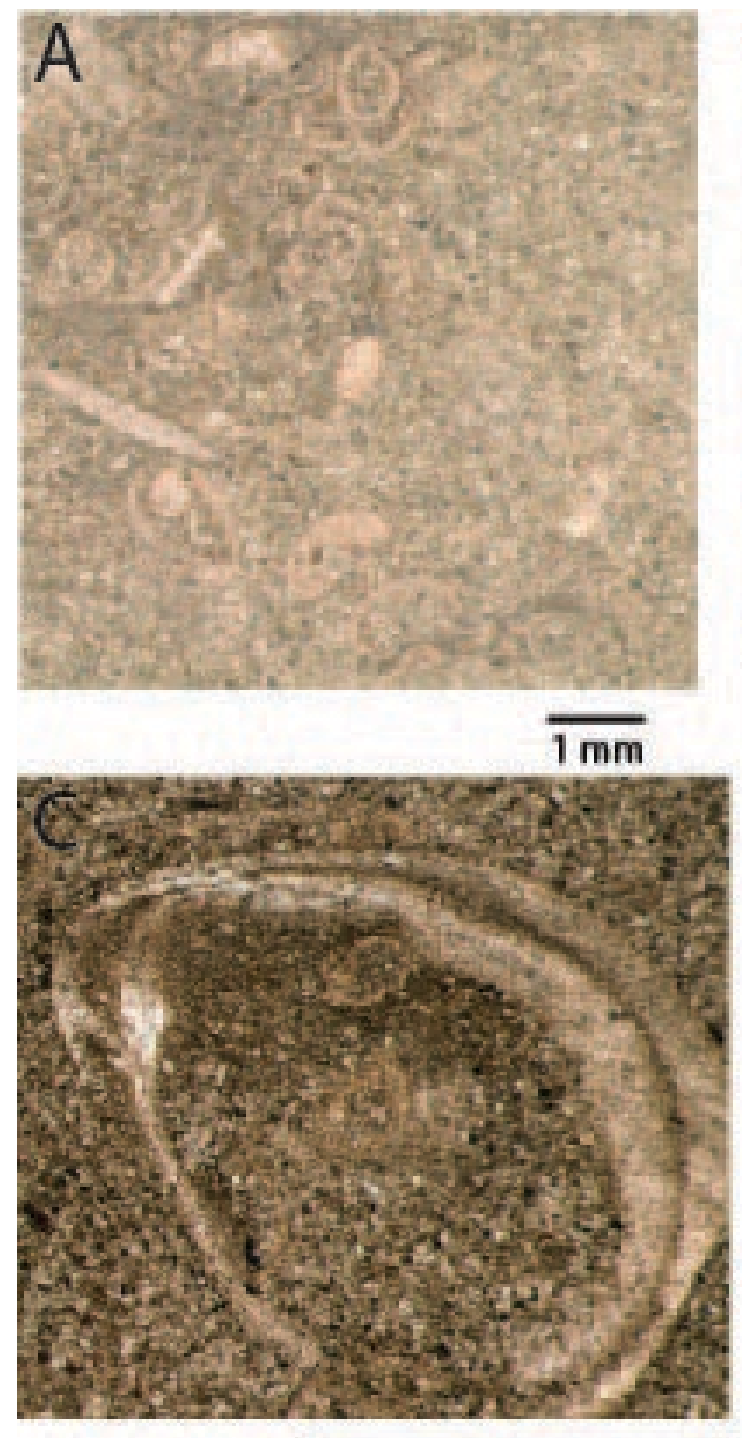

$3 \mathrm{~mm}$

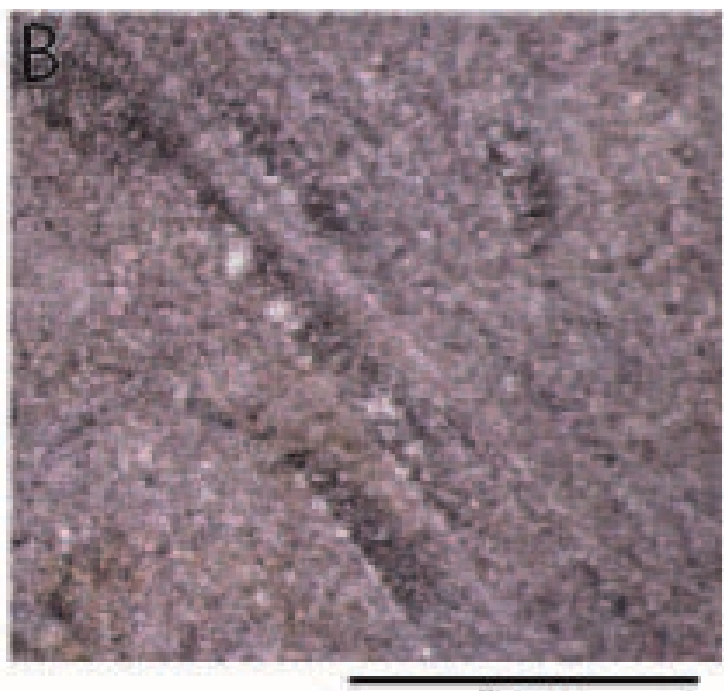

$2 \mathrm{~mm}$
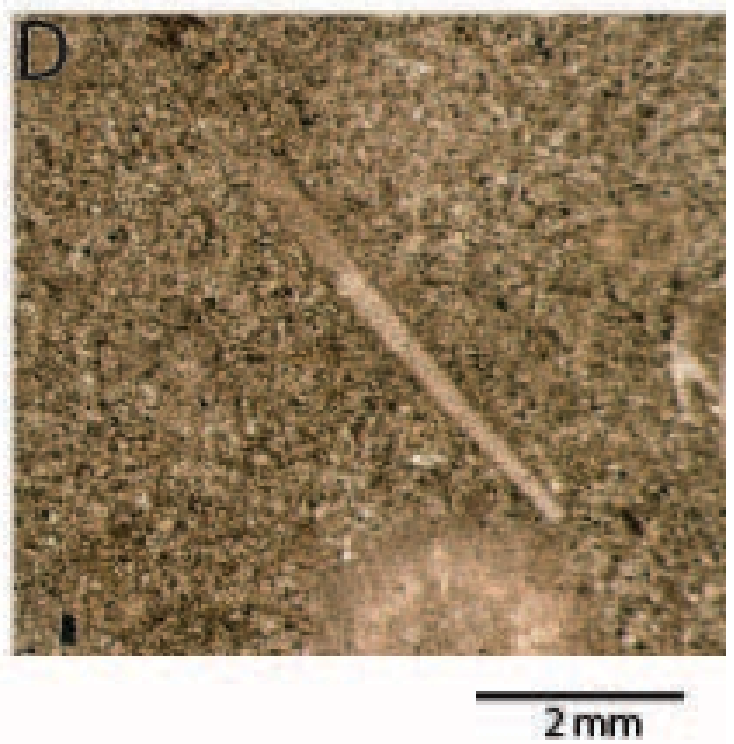

Figure 17: Petrography of a peloidal skeletal grainstone horizon from sample $3 \boldsymbol{E}$, profile 3. A. Abundance of ostracod valve fragments.

B. Encrusting bryozoan.

C. Bivalve or brachiopod shell filled with calcite cement and silt-sized peloidal grains. D. Crinoid columnal. 




$5 \mathrm{~mm}$

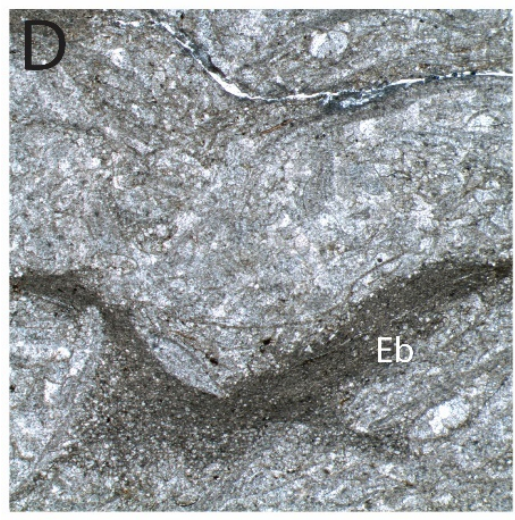

$5 \mathrm{~mm}$

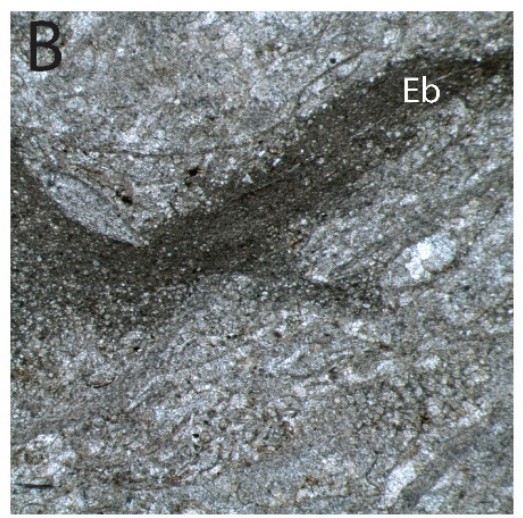

$5 \mathrm{~mm}$

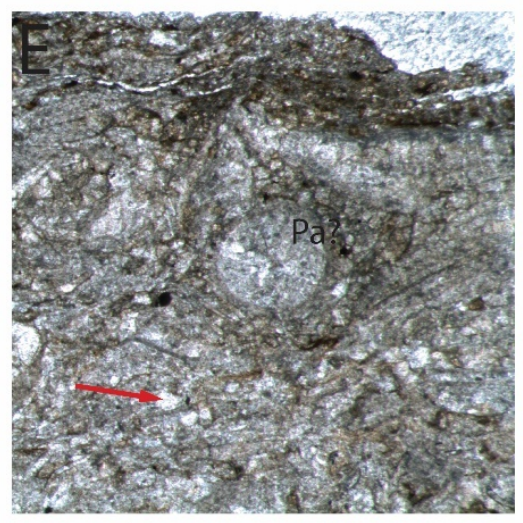

$2 \mathrm{~mm}$



$5 \mathrm{~mm}$

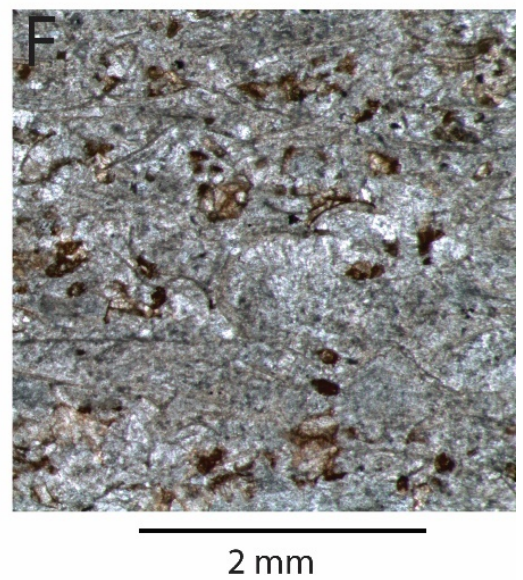

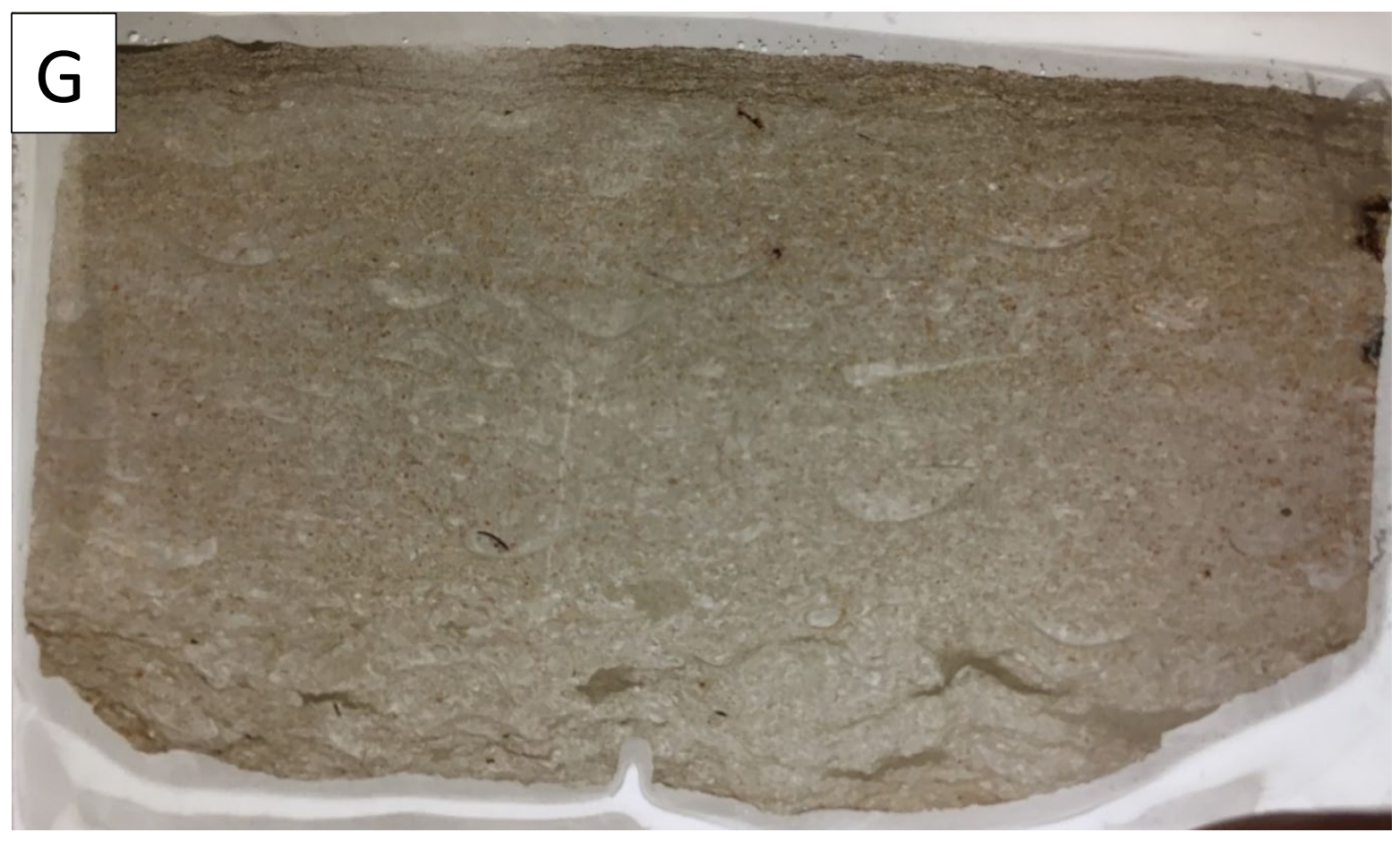


Figure 18: Petrography of recrystallized bioclastic packstone (L6) from sample 3J in profile 3. A. (Red arrow: spar-filled vug or may represent replacement of ostracod valve; small black arrows: encrusting bryozoan; circled: shell fragments).

B. Encrusting bryozoan (Eb).

C. Styolites in a bioclast-rich matrix.

$D-F$ Meteroic diagenesis indicates subaerial exposure during Sea level lowstands. Features include dissolution, drusy and blocky calcite cement, and iron mineral precipitation. (Red arrow = recrystallized calcite crystal; Eb = encrusting bryozoan)

$G$. Photo of sample $3 J$ thick section slab, showing an alignment of convex-up valves and muddy wavy laminae at very top of the bed.



$13 \mathrm{~mm}$

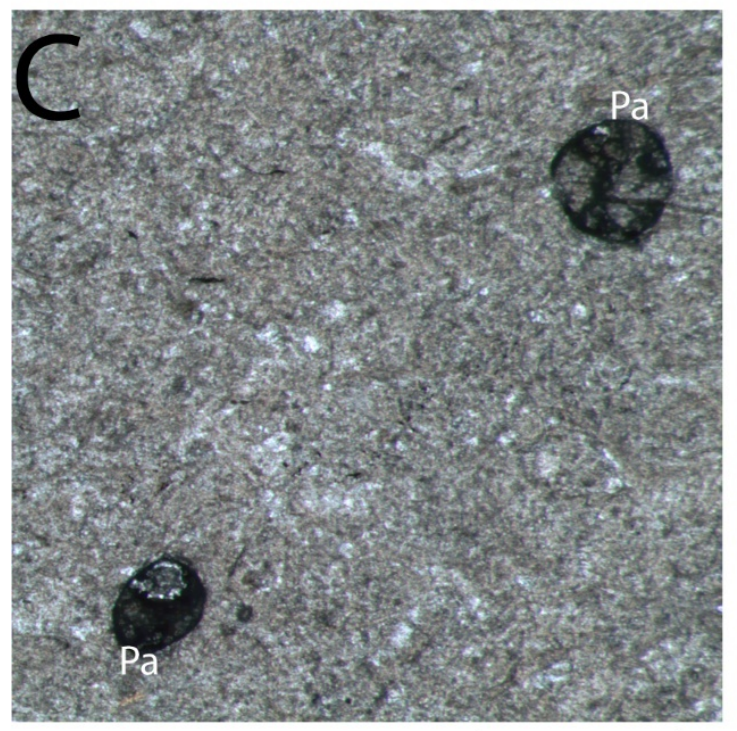

$1 \mathrm{~mm}$



$5 \mathrm{~mm}$

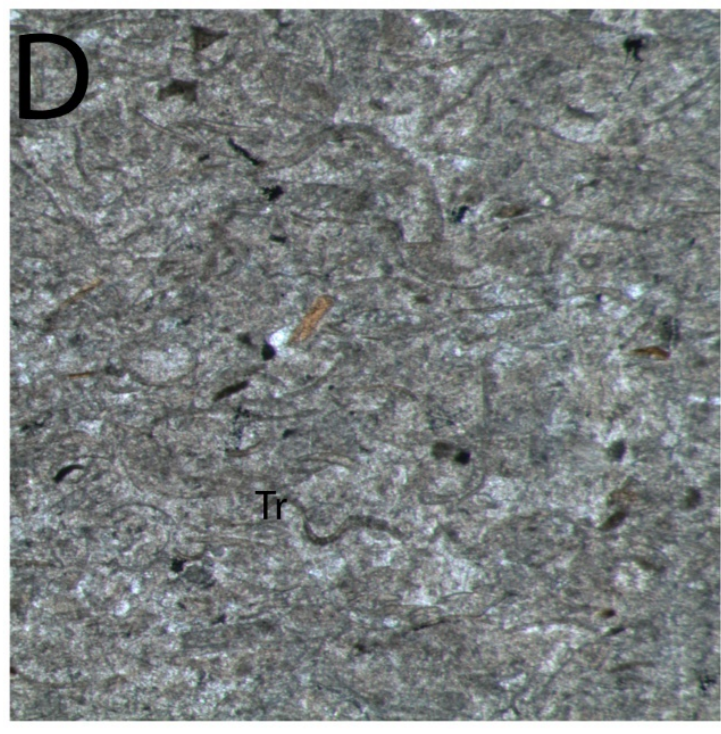

$1 \mathrm{~mm}$ 
Figure 19: Petrography of peloidal skeletal packstone-grainstone, sample $3 F$ from profile 3. A. In the lower portion of this section, planar to ripple-laminations are present, grading up into a more carbonate-rich packstone with fewer siliciclastic grains. A vertical burrow is observed obscuring laminations $(\mathrm{Br})$

B. Potential sponge fossil (Sp).

C. Palynomorphs $(\mathrm{Pa})$ in a recrystallized bioclastic packestone layer.

D. Trilobite fragments (Tr) and ostracod valves. 


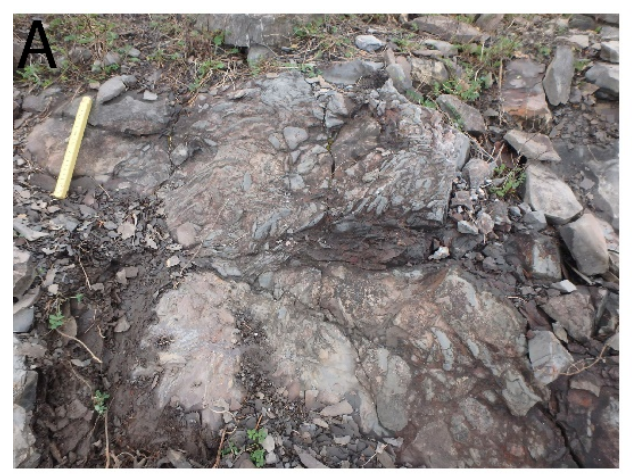

$30 \mathrm{~cm}$
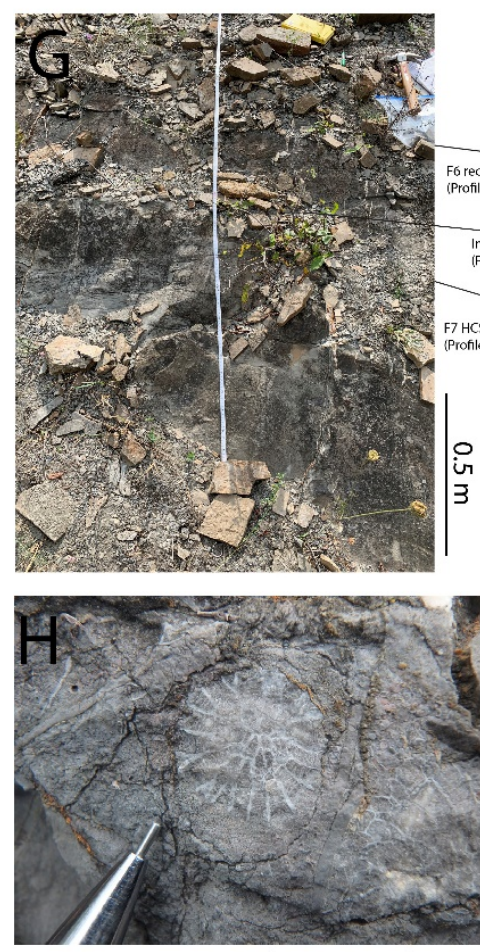

$1 \mathrm{~cm}$

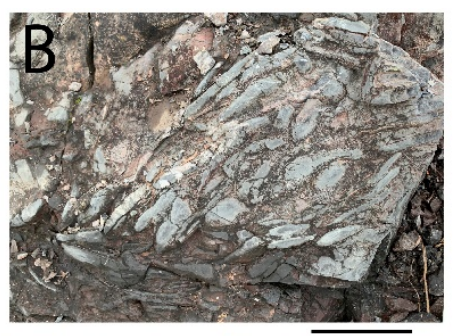

$5 \mathrm{~cm}$

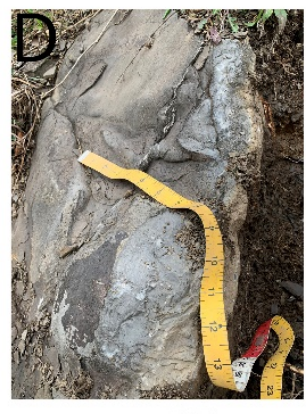

$\overline{8 \mathrm{~cm}}$

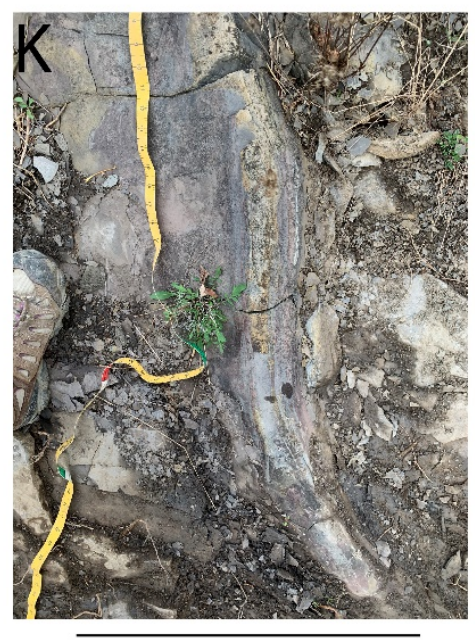

$0.5 \mathrm{~m}$

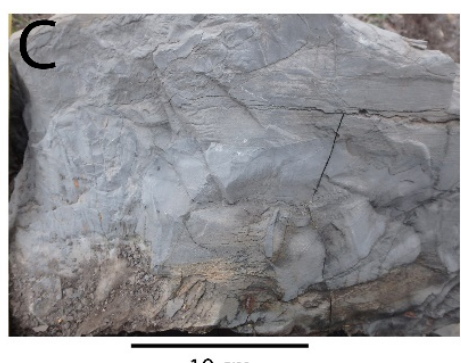

$10 \mathrm{~cm}$


$30 \mathrm{~cm}$

Figure 20: A-B. Intraclast-rich beds in outcrop.

$C$. Detrital carbonate bed.

D-E. Buckled bedding surface with cut and fill structures.

F. Outcrop view of hummocky cross-stratified sandstone onlapped over conglomerate, showing amalgamation surface.

G. Outcrop view of boundary between intraclastic conglomerate (L7) and a bed of recrystallized bioclastic packestone (L6).

H. Fenestrate Bryozoan in center focus. Also viewable: tiny ostracod valves and elongated, flattened-cylindrical micritic intraclasts.

I. Firmgrounds surface associated with channel-form feature in K.

$J$. Close up of firmground surface showing isolated stromatolites.

$K$. Channel-form feature at base of intraclastic conglomerate succession.

L. Thrombolites on bedding surface. 
BS 3

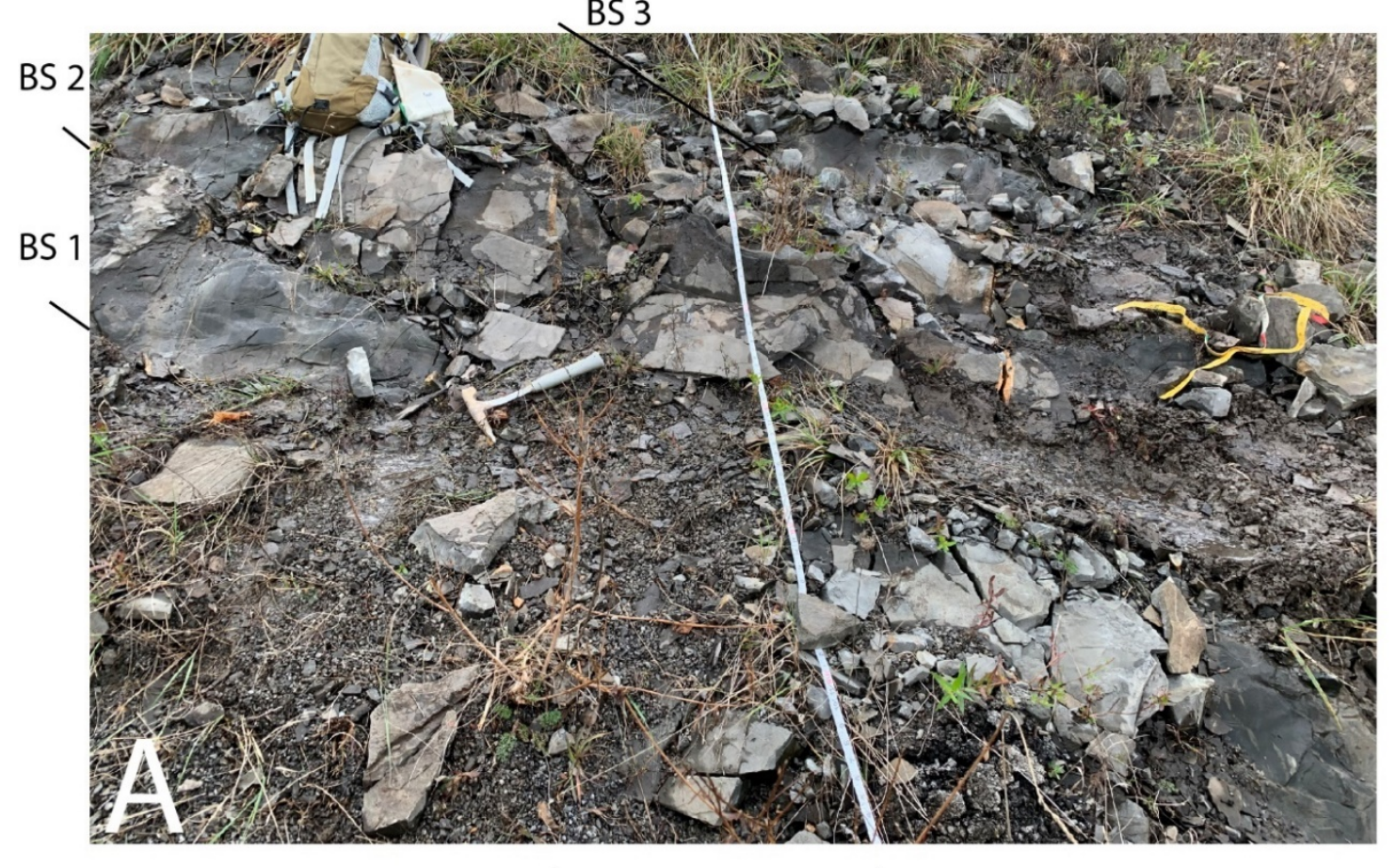

$\sim 1 \mathrm{~m}$

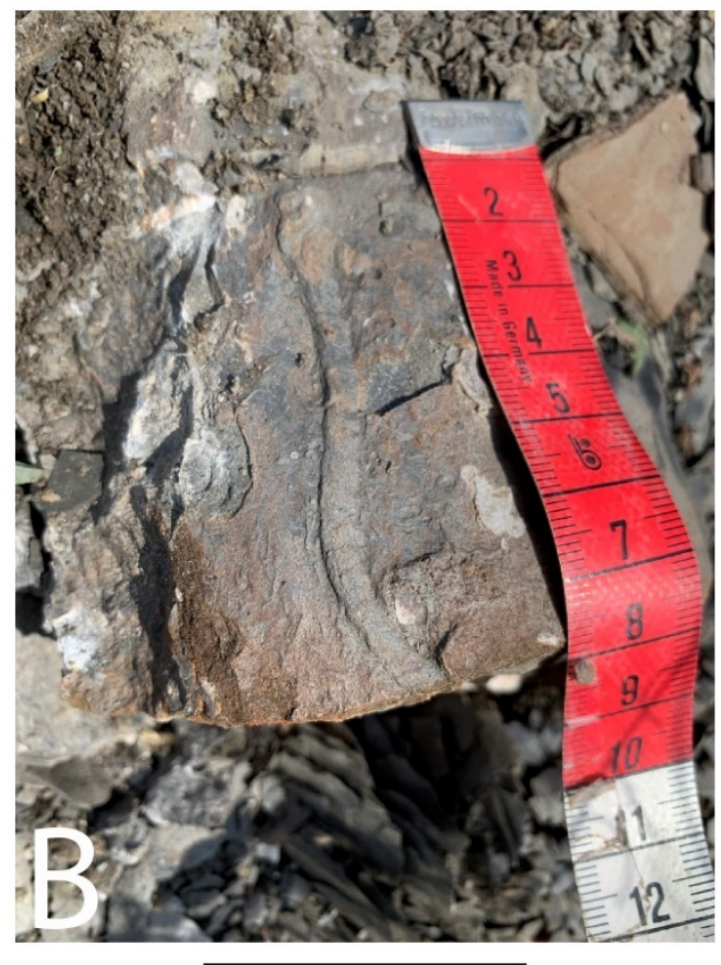

$5 \mathrm{~cm}$



$10 \mathrm{~cm}$ 


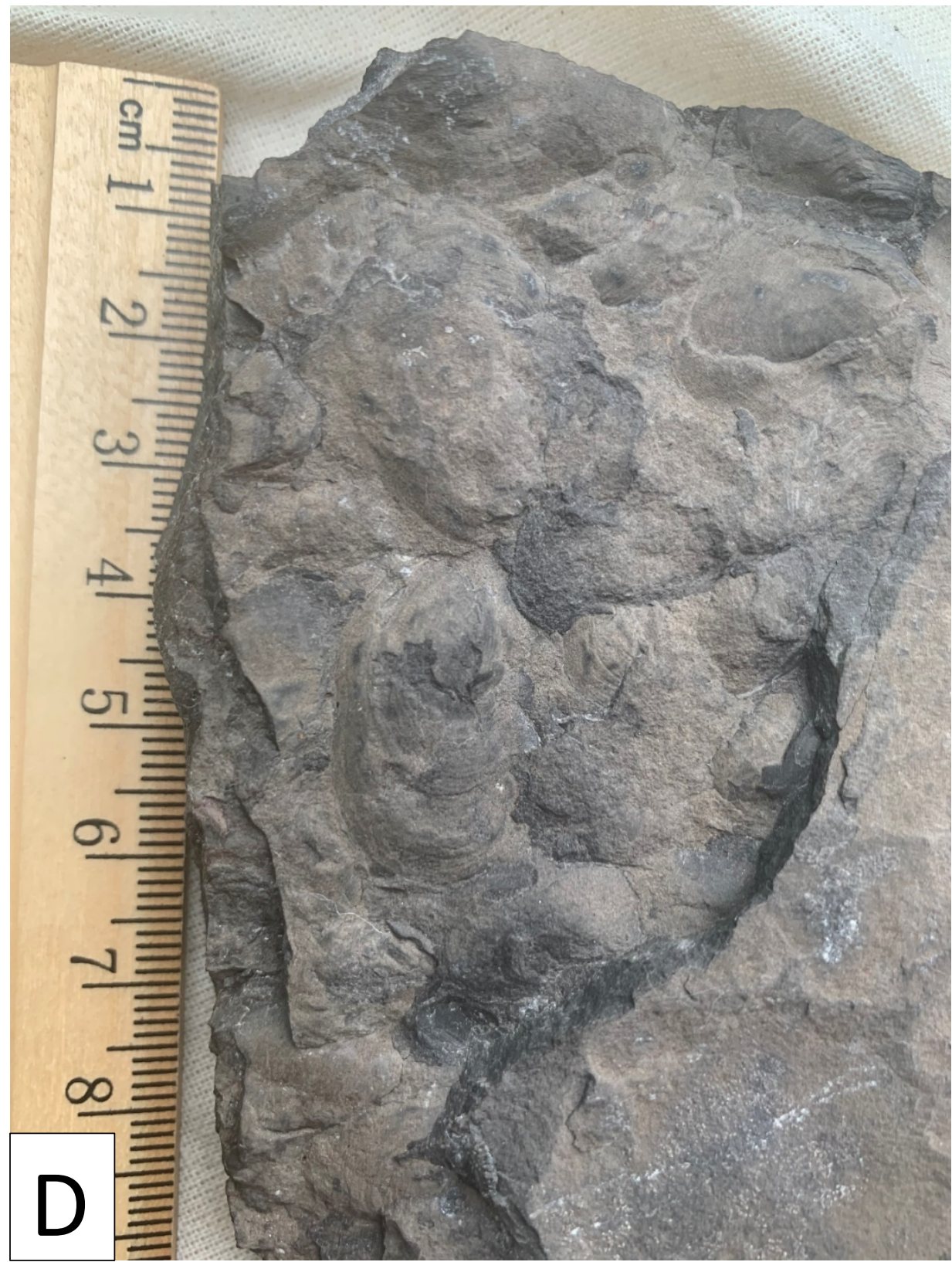

Figure 21: A. Outcrop view of massive microcrystalline carbonates interbedded with brown calcareous mudstone (Corresponds to beds $1-5$ in profile 5; $B S=$ bedset). B. Scoyenia trace fossil shown on bedding base, suggestive of Lingula. $C$-D. Bivalve-rich horizons in thin, flaky calcareous siltstone successions (L9) D. Fossil assemblage of the bivalve Leiopteria. 
Fossil Fauna of the Bloomsburg/Mifflintown Localities, central PA

\section{Bloomsburg}

Unfossiliferous

Lewisburg

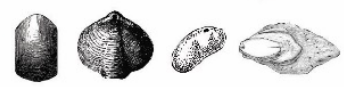

Beavertown
Danville

010

\section{Selinsgrove}

(3) 91

Mill Hall

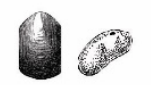

Milton

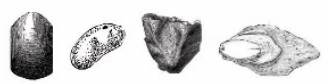

Q

Loysville

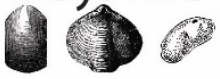

Strodes Mill

Mifflintown

0000 S

Licking Creek

00002

Mt. Union

- 0001

Bedford

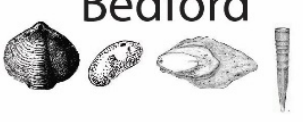

Neff Mills



Hollidaysburg

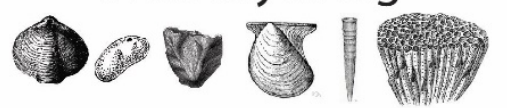

Lewistown




Bellwood

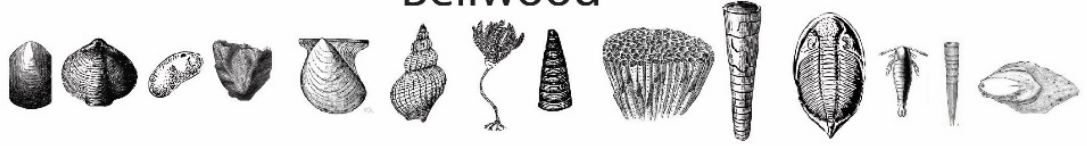

Figure 22: Illustration of observed fossil fauna across the various Bloomsburg localities in central Pennslyvania. 